\title{
Late Middle Palaeolithic assemblages with flake cleavers in the western Pyrenees: The Vasconian reconsidered
}

\section{Q7 Marianne Deschamps}

UMR 5608 TRACES, Maison de la recherche, 5 allée Antonio Machado, 31058 Toulouse Cedex 9, France

\section{A R T I C L E I N F O}

\section{Article history:}

Available online $\mathrm{xxx}$

\section{Keywords:}

Late Middle Palaeolithic

Neanderthal behaviour

Technoeconomic variability

Vasconian

Regionality

\begin{abstract}
A B S T R A C T
The analysis of several lithic assemblages with flake cleavers and bifaces from sites attributed to MIS 5 and 3 in the western Pyrenees provides the basis for a new chronological and typo-technological characterisation of the region's late Middle Palaeolithic record. Previously assigned to the Vasconian based strictly on typological criteria, a certain degree of variability evident between the analysed assemblages likely indicates different occupation types. However, broad typo-technological traits reflecting a common regional tradition can be identified and are discussed against the backdrop of the regional diversity and cultural geography of late Middle Palaeolithic industries dated to around $50 \mathrm{ka}$ BP. This 'regionalisation' of lithic techno-complexes may also have important ramifications for the socioeconomic organisation and demographic dynamics of late Middle Palaeolithic human groups.
\end{abstract}

(C) 2016 Elsevier Ltd and INQUA.

\section{Introduction}

Despite the Western European Middle Palaeolithic portraying substantial technological diversity, certain techno-complexes in this expansive region were quickly isolated and defined, with others remaining the subject of debate. This is particularly the case with assemblages containing bifaces or flake cleavers in the western Pyrenees and on the northern slopes of the Cantabrian cordillera. The first Middle Palaeolithic industries were documented in this region at the end of the 19th century, most notably at the Spanish site of El Pendo (Sanguino González and Montes Barquin, 2001). Despite numerous excavations during the first few decades of the 20th century (Vega del Sella, 1921; Obermaier, 1924, 1925), the existence of a regional Middle Palaeolithic facies, the Vasconian, was proposed only as early as the 1950s based essentially on typological criteria (Bordes, 1953). Defined primarily by the presence of flake cleavers, these assemblages contain high numbers of scrapers (close to the limit of Bordes' Charentian index) and denticulates associated with Levallois debitage (Bordes, 1953). The coherence of this entity was, however, quickly questioned. In fact, the substantial typological variability of these assemblages appeared to some beyond what should be expected of a welldefined cultural entity (Freeman, 1966, 1969-70; Jordá Cerdá, 1977; Cabrera, 1983, 1984; Rodríguez Asensio, 1983).

\footnotetext{
E-mail address: mardesch1690@gmail.com.
}

Consequently, the term 'Vasconian' was largely abandoned and the different industries containing flake cleavers subsequently reassigned to other broad Middle Palaeolithic facies, namely the Mousterian of Acheulean Tradition (MTA) or the Typical Mousterian (Freeman, 1994).

In this respect, both flake cleavers and bifaces from MIS 5 contexts were interpreted as the sporadic persistence of the Iberian Acheulean (Jordá Cerdá, 1977; Rodríguez Asensio, 1983; Rodríguez Asensio and Arrizabalaga, 2004; Álvarez-Alonso, 2014), with the presence of these heavy duty tools in MIS 3 contexts suggesting their continued use throughout the Middle Palaeolithic. While MIS 3 examples are noted in the literature (Freeman, 1966, 1969-70; Cabrera, 1983, 1984) and described in some detail (see particularly the work of Benito del Rey, 1972-73, 1976; 1979, 1981) more focused attention has been paid to flake cleavers from MIS 5 contexts (Rodríguez Asensio, 1983; Montes, 2003). These tool forms in late Middle Palaeolithic assemblages were sometimes considered variants of typical MTA bifaces, whose particular form likely reflected limitations imposed by poor-quality Pyrenean raw materials (Chauchat, 1986; Freeman, 1994). Ultimately, these industries were perceived as the expression of a cultural mosaic set apart from the MTA industries of the northern Aquitaine Basin. However, it remains unclear whether differences between these assemblages reflect deterministic factors, such as raw material availability, or the existence of a regional MIS 3 techno-complex distinct from the MTA. 
Recently, early Middle Palaeolithic (MIS 5) assemblages containing flake cleavers and bifaces have been extensively revised, particularly with a view to better identify late Acheulean occupations in the Cantabrian region and the emergence of the early Middle Palaeolithic (Montes, 2003; Djema, 2008; Lazuén, 2012; Álvarez-Alonso, 2012, 2014; Santonja et al., in press). Late Middle Paleolithic assemblages (MIS 3) with flake cleavers have been identified in the Basque country and Cantabrian and Asturian regions of Spain, as at the El Castillo, level 20 (Cabrera, 1984; Bernald de Quiros et al., 2010), Amalda, level VII (Baldeon, 1990; RíosGaraizar, 2012), La Viña, level XIII-base (Fortea, 1998; Santamaria, 2012). An important synthesis of all known Middle Palaeolithic cave deposits and open-air sites in the Cantabrian Region (Carrión, 2003; Carrión et al., 2008) revealed sites containing flake cleavers and bifaces to be distributed across the region during MIS 5 and 3 based on relative and absolute chronology. However, the chronological position of most sites remains difficult to establish with any 1 certainty (Fig. 1).

Here we present an analysis of material from six either new or recently reassessed late Middle Palaeolithic sites with bifaces and flake cleavers in southwestern France, focusing attention on their typo-technological variability. Do, for example, flake cleavers found in assemblages with particular recurrent characteristics reflect a techno-complex whose differential expression is connected to the nature of the occupation? These new results are compared with other sites from Cantabria and Asturias in a broader regional perspective in order to reconsider the coherence of a Vasconian techno-complex during the MIS 3. In addition to addressing the issues outlined above, this more refined vision of flake cleaver industries has important repercussions for our understanding and interpretation of late Middle Palaeolithic technological variability.

\section{Material and methods}

\subsection{Techno-economic approach}

As post-depositional processes, particularly in cave and rock shelter contexts, have been shown to considerably affect archaeological assemblages (Lenoble and Bordes, 2001; Lenoble, 2003), the typo-technological integrity of each lithic assemblage was first assessed using a detailed taphonomic analysis. Vertical projections of piece-plotted artefacts (Gifford-Gonzalez et al., 1985) combined with a consideration of lithic surface alterations (Thiébaut et al., 2010) and an inter- and intra-layer refitting program (Cahen and Moeyersons, 1977; Bordes, 2002) allows the type and degree of post-depositional disturbance to be evaluated.

Lithic techno-economy is based on the chaîne opératoire concept (Tixier, 1978), which traces a technical process from raw material acquisition to artefact discard. Not only does this approach allow the geographic organisation of the process to be investigated, it can also reveal the extent of a territory exploited by humans groups as well as the manner in which they coped with local and regional environmental conditions. Moreover, when combined with detailed provenance studies the chaîne opératoire concept can help identify the form in which particular raw materials were introduced to sites and for what end. A four-phase conceptualisation of lithic production systems (Geneste, 1985) reveals both the degree of spatiotemporal fragmentation of the chaîne opératoire (e.g. Turq et al., 2013) and the anticipation of needs. When combined, these aspects provide important information concerning the technoeconomic organisation of late Middle Palaeolithic groups.

Several Middle Palaeolithic flaking methods have been identified (e.g. Discoid, Levallois, bifacial shaping), several of which continue to be the subject of debate, particularly the distinction of between certain Levallois and Discoid modalities (Boëda, 1988,
1993, 1994; Van Peer, 1992; Peresani, 2003). The identification of variability in both Discoid chaînes opératoires and production objectives at numerous sites has, however, shed light on clear differences with Levallois industries, leading to a larger discussion concerning the technological variability of the Discoid method(s) and their definition. Although still lacking a general consensus, it is clear that the traditional criteria (Boëda, 1993) differentiating Levallois and Discoid concepts are insufficient, and only a technological analysis of debitage products and associated cores permits a reliable identification of production objectives (Mourre, 2003a). While the 'classic' Discoid method is oriented towards the serial production of pseudo-Levallois points (Boeda, 1993; Bourguignon and Turq, 2003; Bourguignon et al., 2011), a centripetal conception has also been identified that produces more quadrangular flakes from what can at times be hierarcherised surfaces (Mourre, 2003; Pasty, 2003). Here the Discoid method sensu stricto, which is geared around the production of pseudoLevallois points, is distinguished from a sensu lato method that produces more centripetal products (see Mourre, 2003a for more details).

The techno-economic and morphometric variability of flake cleavers was also assessed using a sample of 449 examples from ten Middle Palaeolithic sites. Flake cleavers from sites without direct dates were equally included to have a largest sample. Variance analyses (ANOVA) of length to width ratios for the four main samples $(n>20)$ was used to establish whether significant differences exist between assemblages. The Mousterian sample was also compared to an Acheulean dataset (after data available in Benito del Rey, 1983; Mourre, 2003b) in order to test for diachronic differences in flake cleaver morphology.

\subsection{Studied assemblages}

For the present study, late Middle Palaeolithic levels from four open air sites, level 40 of Le Chemin de Jupiter (Bayonne, France); level PM1 of Le Prissé (Bayonne, France); level 4 of Le Basté (Bayonne, France) and UPS 3 of Latrote (Landes, France) and two cave sites, level Askf1 from Olha II (Cambo-les Bains, France) and a subsample of Cjr level of Gatzarria (Ossas-Suhare, France), were studied. All lithic objects larger than $2 \mathrm{~cm}$ were analysed and, when assemblages contained numerous flakes smaller than $2 \mathrm{~cm}$, as with Olha and Gatzarria, retouch flakes were isolated in order to identify the degree of tool resharpening as well as economic trends between occupations.

Rescue excavations are currently responsible for the majority of Palaeolithic open-air sites discovered in southwestern France. Here, we focus on three such sites discovered around Bayonne (PyrénéesAtlantiques): Le Basté, excavated towards the end of the 1960s (Chauchat and Thibault, 1968), alongside Le Prissé and Le Chemin de Jupiter, excavated by the Inrap in 2010 and 2012, respectively (Colonge et al., 2015). These sites, separated by only a few hundred metres, share identical sedimentary contexts on the Saint-Pierred'Irube plateau and consist of one or several late Middle Palaeolithic occupations in similar stratigraphic positions. Both Jupiter and Prissé have been directly dated by OSL and TL, respectively (see below; Colonge et al., 2015). The archeological levels of Basté, Prissé, and Chemin de Jupiter are all preserved in either hydrographic (paleo-channels) or crypto-karstic (dolines) depressions on the Saint-Pierre-d'Irube plateau (see Colonge et al., 2015; for more details). Surface alterations of the lithic material (Claud in Colonge et al., 2015), its distribution, as well as the numerous refits (for more details see Deschamps, 2014; Clark, 2015) indicate minimal post-depositional disturbance of all three assemblages. A series of small, manually excavated zones and an examination of the sieved material nevertheless indicates a paucity elements smaller than 


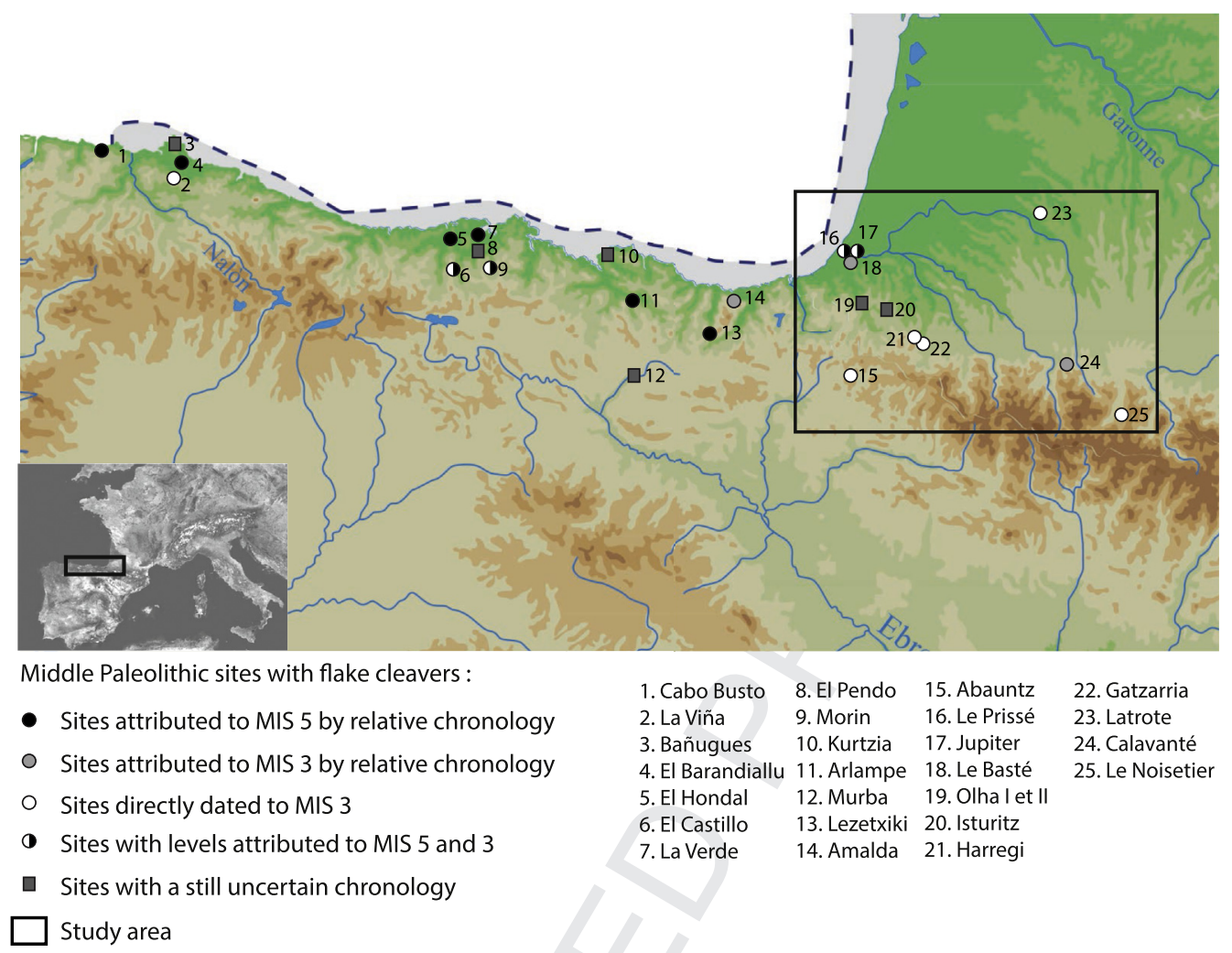

Fig. 1. Study area and distribution of Middle Palaeolithic sites with assemblages including flake cleavers from MIS 5 and 3.

$2 \mathrm{~cm}$, a phenomenon connected to diffuse slope-wash across relatively gentle inclines (Colonge, pers. comm.).

A fourth open-air site, Latrote, in the Landes department was also analysed. Discovered in 2009 during construction of the A65 motorway (Bernard-Guelle et al., 2014), the site is situated atop a hill, with the archeological material found dispersed within a uniformly soliflucted deposit. The location of the site at the limits of an arid zone and the limited number of late Middle Palaeolithic sites with relatively homogenous archaeological material in the region makes Latrote particularly interesting. Moreover, the site lies outside the known geographic limits of the Vasconian. This open-air site, however, poses more significant problems in terms of preservation. The archeological material, originally deposited on the top of small hill, was found remobilised by solifluction on the eastern slope. While contained within a homogeneous deposit, the random distribution of the refit sets indicates the lack of any intact spatial organisation (Bernard-Guelle et al., 2010, 2014). Furthermore, elements smaller than $2 \mathrm{~cm}$ are systematically absent from the sieved fraction, suggesting a residual deposit. Despite these issues, the surfaces of the lithic material nevertheless preserve traces of use. Numerous refits, the typotechnological and taphonomic homogeneity of the assemblage, as well as the limited vertical displacement of the artefacts, suggest the mass transport of a single occupation level (BernardGuelle et al., 2010, 2014).

First discovered in 1950, the cave of Gatzarria, excavated by G. Laplace between 1961 and 1976 (Laplace and Saenz de Buruaga, 2002), contains an uninterrupted stratigraphic sequence documenting the Middle Palaeolithic to Gravettian. Like numerous cave and rockshelter sites on the northern slopes of the Pyrenean foothills, the early date of site's initial excavations means that the integrity of the Gatzarria sequence requires a detailed technological reevaluation combined with a taphonomic and stratigraphic assessment of the deposits. Finally, the complex stratigraphic sequence of Gatzarria is partially disturbed by numerous postdepositional processes, including slope-wash and burrowing. The layers generally slope towards the karstic tube at the back of the cave, with only the area at the cave's entrance preserving a succession of sub-horizontal layers. Clear typo-technological incoherencies indicative of the post-depositional mixing of material are also evident between the cave's entrance and the back of the cavity. Moreover, vertical projections of culturally diagnostic elements from layer $\mathrm{Cjr}$ at the back of the cave reveal the presence of two superimposed and partially mixed assemblages that were not identified by Laplace. The lowermost layer contains diagnostic Quina Mousterian elements and is overlain by assemblages composed primarily of scrapers, denticulates and flake cleavers. Estimating the degree of admixture, however, requires the systematic testing of debitage and break conjoins between these two levels (Deschamps, 2014). As a general taphonomic analysis of the entire Gatzarria Mousterian sequence is currently in progress, we analysed only a subsample of material from level Cjr excavated by Laplace at the entrance of the cave where stratigraphic disturbances are less problematic.

Finally, the site of Olha I, located at the base of cliff and containing only Mousterian deposits, was discovered in 1917 and first excavated between 1917 and 1919 (Passemard, 1924), with a second zone, Olha II, explored between 1947 and 1977, and then again between 1971 and 1977 (Laplace and Saenz de Buruaga, 2000). While no absolute dates are currently available, the lower layers of Olha I (Passemard excavations) have been assigned to MIS 5 based on the paleontology of associated cervid remains compared with those recovered from Combe Grenal in the northern Aquitaine Basin (Guadelli, 1987, 1996). However, the persistence of Cervus simplicidens throughout the Olha I sequence (Deschamps, 2014) and their replacement by Cervus elaphus at Combe Grenal (Guadelli, 

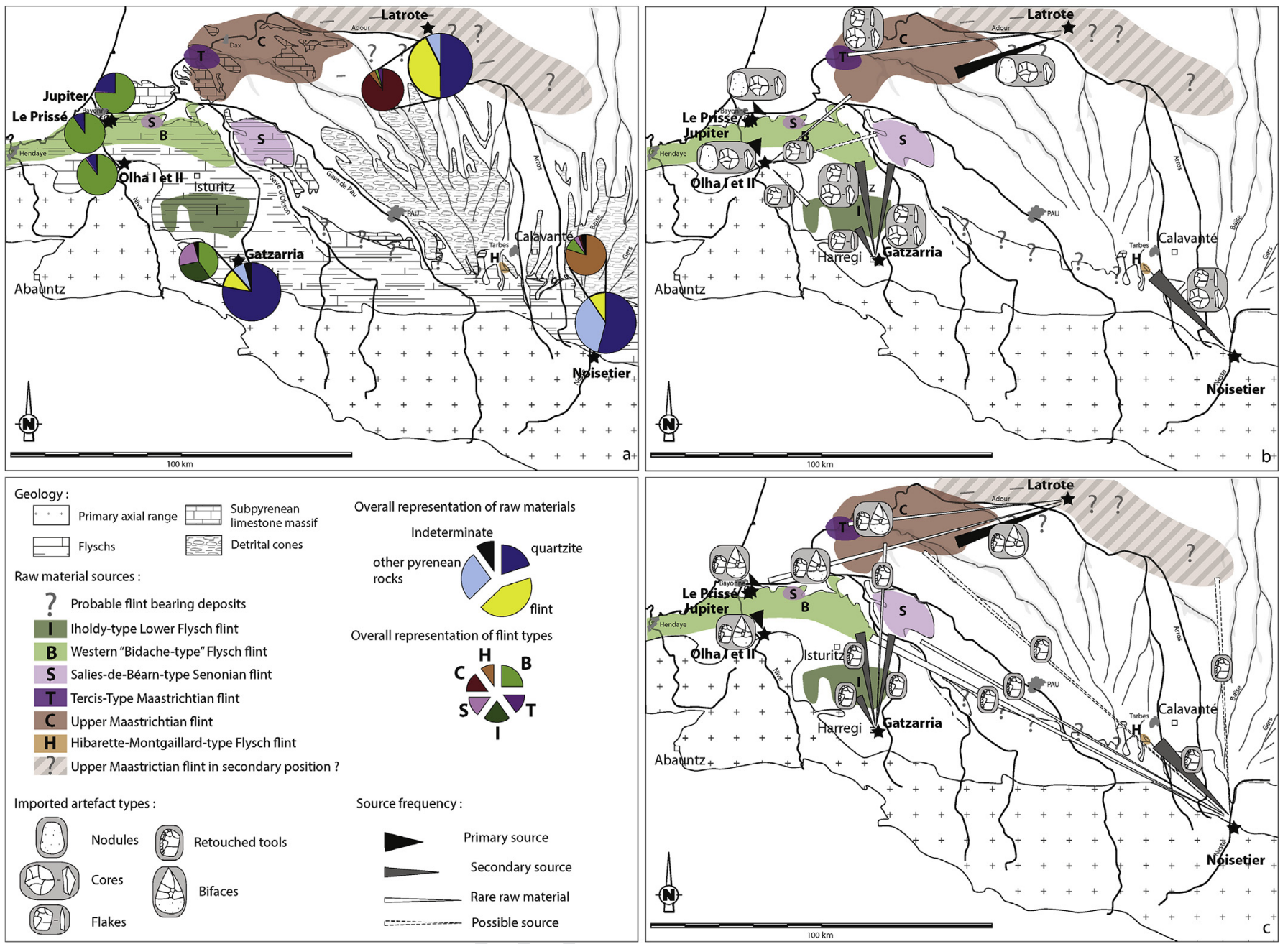

Fig. 2. Origin and circulation of lithic raw materials (Data for Noisetier Cave and Latrote are from Thiébaut et al., 2012 and Bernard-Guelle et al., 2014; respectively). a: Percentages of different raw material in each studied assemblage. b: Circulation of blocks, cores and blanks. c: Circulation of retouched tools and bifaces.

1987, 1996) more likely reflect different environmental conditions between the two regions rather than chronology.

Vertical projections of the material recovered during Laplace's excavation reveal only the deposits at the base of the cave to be subhorizontal and sealed by an approximately $1 \mathrm{~m}$-thick sterile layer composed of large blocks of roof fall connected to the total collapse of the cave overhang. The overlying layers slope heavily towards the north, an orientation likely resulting from the introduction of colluvial deposits from the summit of the plateau. Consequently, these layers are almost certainly affected by considerable postdepositional reworking. Therefore, only the uppermost layer (Askf1) from Laplace's excavation at Olha II and hence, the most recent undisturbed archaeological assemblage from the lower sequence was studied.

\section{Results}

\subsection{Raw material procurement}

The geology of the western Pyrenees comprises a mosaic of structural elements: the Aquitaine Basin, the Sables des Landes, and the northern Pyrenean area containing cretaceous Flysch and the Pyreneean mountain range. Flint sources are unequally distributed across the region, found principally in sedimentary basins. These fairly diverse sources are however well characterised following numerous raw material surveys since the 1980s (Normand, 1986, 2002; Bon et al., 2002; Séronie-Vivien, 2006; Tarriño, 2006; Colonge et al., 2011; Fernandes, 2012; Séronie-Vivien et al., 2012; Minet, 2013; Tarriño et al., 2014). The most important lithic raw material is without doubt Flysch flint that outcrops from the Gaves in the Landes departement to Bilbao in northwestern Spain. Alongside this predominant raw material, more localised flint sources were also exploited, including Lower Cretaceous flint from Iholdy, Salies-le-Bearn-type Senonian flint and Upper Maastrictian flint from Tercis and the Chalosse area (Fig. 2a).

Additional raw materials, principally fine-grained quartzite, as well as quartz (filonian or hyalin), ophite, shist, mudstones or cinerites, were procured from alluviums and terraces in the Pyrenean mountain chain. The abundance of these different raw materials available in secondary positions in nearly all regional river beds makes identifying their precise origin extremely complicated. However, several studies have provided more detail concerning the availability and distribution of raw materials in the Garonne (Bruxelles et al., 2012) and Neste valleys (Deschamps et al., 2011; Deschamps, 2014), with more work still needed for the Adour, Nive and Saison valleys.

The diversity of lithic raw materials from the southern Aquitaine Basin is relatively well characterised (see references above), 
allowing patterns of raw material circulation to be identified. Convergent provisioning strategies in the sites studied suggest the exploitation of the same general territory (Fig. 2). The importance of lithic raw materials from the Aquitaine Basin in these assemblages is further highlighted by the fact that these sources are also found on sites at the margins of their core area. For example, at Noisetier Cave and Latrote local resources to the north and east were not exploited. Moreover, the apparent absence of Danian flint from the Petites Pyrénées region in layer 1 of Noisetier Cave some $50 \mathrm{~km}$ to the north-east (Chalard in Thiébaut et al., 2012) indicates the arrival of groups from the west and a preferential south to east and north to east mobility pattern. However, at Latrote, there are also a small number of artefacts $(n=14)$ made on raw materials found to the north on the left bank of the Garonne (Fernandes, 2012).

The form in which materials are introduced to sites also differs as a function of their distance from the source. Raw materials accessible within $20 \mathrm{~km}$ are imported as blocks or preformed cores, which are than reduced on-site, whereas materials from sources between 20 and $50 \mathrm{~km}$ are introduced either as cores or, most often, flake tools. Finally, more exotic raw materials are almost exclusively found as flake tools or bifaces. The circulation and form in which raw materials are introduced reveals a territorial exploitation system partially structured around access to high-quality raw materials. With that said, occupations at the margins of these zones provide evidence for the primary exploitation of local sources (quartzite, ophite, quartz, schist or cinerite) and the importation of high-quality flints over distances of between 50 and $100 \mathrm{~km}$ (Fig. 2b,c).

\subsection{Flake chaînes opératoires}

The same Discoid chaîne opératoire geared around the production of flakes that remove only a limited portion of the core's edge and pseudo-Levallois points dominate all three open-air sites (Fig. 3; see tables 2 and 3 in Colonge et al., 2015). Unifacial cores are most abundant, with the maintenance of surface convexities sometimes producing a bipyramidal structure. Alternating centripetal and chordale flakes remove only a portion of the core's edge in order to maintain the necessary surface convexities. As cores approach exhaustion, they are reoriented in a more opportunistic manner in order to exploit the remaining convexities, producing multidirectional negatives. The centripetal Discoid method is equally present on quartzite at Gatzarria and Latrote and on flint at Olha. While core morphologies are generally similar to those producing pseudo-Levallois points, debitage is principally centripetal, favouring the production of flakes with peripheral cutting edges (Fig. 3; Tables 1-3). Independent of the raw material concerned the Discoid method is dominant identified on flint at Prissé and Jupiter and quartzite at Gatzarria Cjr level. On the other hand, Levallois products on the same quartzite types from the uppermost level of Gatzarria demonstrate raw material quality not to condition technological choices (Thiébaut et al., 2014).

Table 1

Technological composition of Latrote.

\begin{tabular}{|c|c|c|c|c|c|c|c|c|}
\hline \multirow[t]{2}{*}{ Latrote } & \multicolumn{6}{|c|}{ Raw materials } & \multirow[t]{2}{*}{ Total } & \multirow[t]{2}{*}{$\%$} \\
\hline & Flint & Quartzite & Quartz & Lydian/cinerite & Schist & Other & & \\
\hline Cortical flake & 8 & 74 & 9 & & 2 & & 93 & 3.9 \\
\hline Flake $<50 \%$ cortex & 92 & 64 & 5 & 2 & & 1 & 164 & 6.9 \\
\hline Flake $>50 \%$ cortex & 88 & 48 & 1 & 1 & & 1 & 139 & 5.9 \\
\hline Naturally backed flake & 58 & 70 & 6 & & & 3 & 137 & 5.8 \\
\hline Flake with large convex cortical butt & 19 & 19 & & & & & 38 & 95.0 \\
\hline Convexity management flake & 12 & 11 & & & & & 23 & 1.0 \\
\hline Kombewa flake & 8 & 1 & & & & & 9 & 0.4 \\
\hline Flake & 134 & 73 & 9 & & & & 216 & 9.1 \\
\hline Eclat débordant & 42 & 32 & & 1 & & & 75 & 3.2 \\
\hline Crest (axial and transversal) & 6 & 6 & & & & & 12 & 0.5 \\
\hline Pseudo-Levallois point & 20 & 5 & & & & & 25 & 1.1 \\
\hline Atypical pseudo-Levallois point & 20 & & & & & & 20 & 0.8 \\
\hline Levallois flake & 9 & & & & & & 9 & 0.4 \\
\hline Bifacial thinning flake & 22 & 2 & & & & & 24 & 1.0 \\
\hline Elongated flake & 10 & & & & & & 10 & 0.4 \\
\hline Retouch flake & 10 & & & & & & 10 & 0.4 \\
\hline Flakes $<25 \mathrm{~mm}$ & 175 & 45 & 4 & 1 & & & 225 & 9.5 \\
\hline Fragment & 121 & 45 & 9 & 2 & & 1 & 178 & 7.5 \\
\hline Core-tool & 1 & & & & & & 1 & 0.0 \\
\hline Upper Palaeolithic? & 2 & & & & & & 2 & 0.1 \\
\hline Cores & 80 & 71 & 7 & & 1 & & 159 & 6.7 \\
\hline Bifaces & 6 & 6 & & & & & 12 & 0.5 \\
\hline Flake Cleavers & & 3 & & & & & 3 & 0.1 \\
\hline Pebble Tools & & 7 & & & 1 & & 8 & 0.3 \\
\hline Tested blocks & 7 & 28 & 3 & 1 & 1 & & 40 & 1.7 \\
\hline Hammerstones & 1 & 51 & & & & 1 & 53 & 2.2 \\
\hline $\begin{array}{l}\text { Human-modified pebbles } \\
\text { and fragments }\end{array}$ & 2 & 164 & 16 & 1 & 4 & & 187 & 7.9 \\
\hline Shatter & 42 & 50 & 11 & 6 & & 2 & 111 & 4.7 \\
\hline Untested block & 1 & 312 & 24 & 3 & 1 & 12 & 353 & 14.9 \\
\hline Indeterminate & 11 & 1 & & & & 21 & 33 & 1.4 \\
\hline TOTAL & 1007 & 1188 & 104 & 18 & 10 & 42 & 2369 & 100 \\
\hline$\%$ & 42.5 & 50.1 & 4.4 & 0.8 & 0.4 & 1.8 & 100 & \\
\hline
\end{tabular}


Table 2

Technological composition of Gatzarria.

\begin{tabular}{|c|c|c|c|c|c|c|c|c|}
\hline \multirow[t]{2}{*}{ Gatzarria } & \multicolumn{6}{|c|}{ Raw materials } & \multirow[t]{2}{*}{ Total } & \multirow[t]{2}{*}{$\%$} \\
\hline & Flint & Quartzite & Filonian/Hyaline quartz & Pelite & Lydian/cinerite & Other & & \\
\hline Cortical flake & 3 & 58 & & 3 & & 3 & 67 & 1.9 \\
\hline Flake $<50 \%$ cortex & 5 & 35 & & & & 2 & 42 & 1.2 \\
\hline Flake $>50 \%$ cortex & 12 & 60 & & 2 & 1 & 1 & 76 & 2.1 \\
\hline Bipolar percussion on anvil & & 18 & 1 & & & & 19 & 0.5 \\
\hline Naturally backed flake & 16 & 118 & & 2 & 1 & 3 & 140 & 3.9 \\
\hline Flake with large convex cortical butt & & 22 & 1 & & & & 23 & 0.6 \\
\hline Convexity management flake & 4 & 21 & & & & & 25 & 0.7 \\
\hline Kombewa flake & 2 & 24 & 1 & & & 2 & 29 & 0.8 \\
\hline Flake & 39 & 490 & 3 & 14 & 2 & & 548 & 15.2 \\
\hline Eclat débordant & 14 & 78 & & 2 & 2 & & 96 & 2.7 \\
\hline Crest (axial and transversal) & 2 & 15 & & 1 & & & 18 & 0.5 \\
\hline Pseudo-Leavllois point & 2 & 20 & & & & & 22 & 0.6 \\
\hline Atypical pseudo-Levallois point & & 10 & & & & & 10 & 0.3 \\
\hline Levallois flake & 1 & 2 & & & & & 3 & 0.1 \\
\hline Bifacial thinning flake & & 8 & & & & & 8 & 0.2 \\
\hline Elongated flake & & 17 & & & & 1 & 18 & 0.5 \\
\hline Retouch flake & 98 & 87 & & 3 & 1 & 1 & 190 & 5.3 \\
\hline Flakes $<20 \mathrm{~mm}$ & 370 & 1561 & 18 & 58 & 10 & 19 & 2036 & 56.4 \\
\hline Cores & 11 & 59 & 3 & 1 & & & 74 & 2.1 \\
\hline Flake Cleavers & & & & & & 6 & 6 & 0.2 \\
\hline Pebble Tools & 1 & & & & & 1 & 2 & 0.1 \\
\hline Shatter & 28 & 114 & 2 & 9 & 1 & 1 & 155 & 4.3 \\
\hline TOTAL & 608 & 2817 & 29 & 95 & 18 & 40 & 3607 & 100 \\
\hline$\%$ & 16.9 & 78.1 & 0.8 & 2.6 & 0.5 & 1.1 & 100 & \\
\hline
\end{tabular}

Table 3

Technological composition of Ohla II.

\begin{tabular}{|c|c|c|c|c|c|c|}
\hline \multirow[t]{2}{*}{ Olha II } & \multicolumn{4}{|c|}{ Raw materials } & \multirow[t]{2}{*}{ Total } & \multirow[t]{2}{*}{$\%$} \\
\hline & Flint & Quartzite & Quartz & Other & & \\
\hline Cortical flake & 36 & 4 & 1 & & 41 & 1.41 \\
\hline Flake $<50$ cortex & 74 & 2 & 3 & 2 & 81 & 2.79 \\
\hline Flake $>50 \%$ cortex & 139 & 7 & 11 & 2 & 159 & 5.48 \\
\hline Bipolar percussion on anvil & & & 2 & & 2 & 0.07 \\
\hline Naturally backed flake & 58 & 4 & 2 & 1 & 65 & 2.24 \\
\hline Flake with large convex cortical butt & 13 & 2 & 1 & & 16 & 0.55 \\
\hline Convexity management flake & 35 & & & & 35 & 1.21 \\
\hline Kombewa flake & 45 & 3 & & & 48 & 1.65 \\
\hline Flake & 302 & 17 & 16 & 4 & 339 & 11.68 \\
\hline Eclat débordant & 105 & 8 & 8 & & 121 & 4.17 \\
\hline Crest (axial and transversal) & 37 & & & & 37 & 1.27 \\
\hline Pseudo-Leavllois point & 30 & 7 & & 1 & 38 & 1.31 \\
\hline Atypical pseudo-Levallois point & & & & & 0 & 0.00 \\
\hline Levallois flake & 3 & & & & 3 & 0.10 \\
\hline Bifacial thinning flake & 80 & & & & 80 & 2.76 \\
\hline Elongated flake & 38 & 1 & 1 & 1 & 41 & 1.41 \\
\hline Retouch flake & 114 & 1 & & & 115 & 3.96 \\
\hline Flakes $<20 \mathrm{~mm}$ & 974 & 12 & 69 & & 1055 & 36.35 \\
\hline Fragment & 17 & 3 & 5 & & 25 & 0.86 \\
\hline Cores & 38 & 4 & 5 & & 47 & 1.62 \\
\hline Bifaces & & & & & 0 & 0.00 \\
\hline Flake Cleavers & & 5 & & & 5 & 0.17 \\
\hline Pebble Tools & & & & & 0 & 0.00 \\
\hline Shatter & 501 & 2 & 36 & & 539 & 18.57 \\
\hline Hammerstones & & 5 & 2 & 3 & 10 & 0.34 \\
\hline TOTAL & 2639 & 87 & 162 & 14 & 2902 & 100 \\
\hline$\%$ & 90.94 & 2.99793 & 5.5824 & 0.4824 & 100 & \\
\hline
\end{tabular}

Discoid debitage geared around the production of pseudoLevallois points is best represented at all three open-air sites while centripetal reduction is more frequent at cave and rockshelter sites in the Pyrenean foothills. Only the material from Latrote demonstrates the clear coexistence of the two production objectives. Moreover, the production of pseudo-Levallois points is found preferentially on silex at Latrote, with centripetal reduction reserved for quartzite. Other flaking methods are rare - preferential or uni- and bi-polar Levallois at Latrote, Prissé and Olha and several examples of the bipolar percussion of quartzite on an anvil exist at both Latrote and Gatzarria. 


\subsection{Bifacial chaînes opératoires}

Despite the presence of bifaces having been noted in the region for sometime, the characterisation of associated chaînes opératoires remains poorly described. Moreover, the production of bifacial tools plays a crucial role in the redefinition of the Vasconian given arguments for the attribution of certain assemblages to the MTA based on the presence of this tool type (e.g. Chauchat, 1985; Soressi, 2002). Bifaces or evidence for their production is present across all the studied sites and, not only are the chaînes opératoires rarely complete, they are considerably fragmented in both space and time. Apart from Olha and Basté, bifaces are consistently imported and resharpened on-site, suggesting substantial mobility and extended use-lives for these tools.

A comparable biface chaîne opératoire was identified at all the studied sites - the active edges are shaped on small slabs or flat nodules, leaving a cortical base that is gradually removed over successive resharpening phases in order to maintain sufficiently long cutting edges. While bifaces retaining cortical surfaces are often lozenge shaped, they tend to be cordiform when entirely worked. Notched bifaces (stage 5 of Fig. 4) or bifaces transformed into cores are frequent in all assemblages. Finally, a particular rejuvenation technique involving a transverse overshot flake that removes both convergent active edges is evident on numerous examples (Fig. 4). Known in the Neolithic of the Near East (Inizan and Tixier, 1978; Charpentier, 1999), this type of edge rejuvenation has never been documented for late Middle Palaeolithic bifacial tools. Although not systematic, its use is evident at the majority of the sites studied, suggesting this technique to represent a genuine regional idiosyncrasy. from open-air sites likely tied to taphonomic factors (see above). Despite these biases, tool to flake ratio clearly differ between the two site types; large cortical blanks are preferentially retouched on open-air sites, while tools are heavily resharpening at cave and rockshelter sites, sometimes rendering identifying the initial blank type impossible. Gatzarria is particularly interesting in this respect as resharpening intensity differs according to raw material. Locally available raw materials are rarely resharpened, while tools made on more distant sources exhibit evidence for successive resharpening episodes.

\subsection{Flake cleavers}

Characteristic of the Iberian Acheulean (Santonja and Villa, 2006; Mourre and Colonge, 2007; Colonge et al., 2014) and also known from MIS 5 contexts, the recurrent presence of flake cleavers is, however, one of the defining elements of the region's late Middle Palaeolithic. Flake cleavers from MIS 3 contexts are systematically produced on locally available raw materials, principally quartzite and ophite (Table 4). Moreover, they are the only tool type tied to the use of specific raw materials, in so much as they are never made on flint despite its local availability and adequate size for the manufacture of such tools. The fact that the unmodified active edge is not conducive to successive resharpening episodes suggests both a shorter use-life and reduced mobility. Like bifaces, flake cleavers are consistently found imported as finished tools, whose production is also spatiotemporally fragmented. Additionally, no late Middle Palaeolithic 'production sites' for this specific tool type are currently known.

Table 4

Late Middle Paleolithic flake cleaver sample by raw material type.

\begin{tabular}{|c|c|c|c|c|c|c|c|c|c|c|c|}
\hline \multirow[t]{2}{*}{ Late middle Paleolithic sites } & \multicolumn{9}{|c|}{ Raw materials } & \multirow[t]{2}{*}{ Total } & \multirow[t]{2}{*}{$\%$} \\
\hline & Quartzite & Ophite & Flint & Limestone & Sandstone & $\begin{array}{l}\text { Quarzitic } \\
\text { sandstone }\end{array}$ & Other & $\begin{array}{l}\text { Other volcanic } \\
\text { raw materials }\end{array}$ & Nodular Schist & & \\
\hline Abauntz & 3 & 3 & & 3 & & & & & 6 & 15 & 3.3 \\
\hline castillo & 162 & 77 & & 1 & 12 & 9 & 1 & 1 & & 263 & 58.6 \\
\hline Gatzarria & & 4 & & & & & & 2 & & 6 & 1.3 \\
\hline Jupiter & 3 & & & & & & & & & 3 & 0.7 \\
\hline Latrote & 3 & & & & & & & & & 3 & 0.7 \\
\hline Morin & 2 & 19 & & & & & & 1 & & 22 & 4.9 \\
\hline Olha Fi3 & 24 & 56 & & 4 & & & & & & 84 & 18.7 \\
\hline Olha Fi4 & 1 & 11 & & & & & 1 & 1 & & 14 & 3.1 \\
\hline Olha2 & & 5 & & & & & & & & 5 & 1.1 \\
\hline Pendo & 10 & 13 & & 1 & 4 & & & & & 28 & 6.2 \\
\hline Prissé & 2 & 4 & & & & & & & & 6 & 1.3 \\
\hline Total & 210 & 192 & 0 & 9 & 16 & 9 & 2 & 5 & 6 & 449 & 100 \\
\hline$\%$ & 46.8 & 42.8 & 0.0 & 2.0 & 3.6 & 2.0 & 0.4 & 1.1 & 1.3 & 100 & \\
\hline
\end{tabular}

\subsection{Retouched tools}

Scrapers are systematically the most abundant tool types in all assemblages (Fig. 5), accompanied by denticulates, notches and limited numbers of other retouched tool forms (e.g. points and "Upper Palaeolithic types"). While sharing the same general morphology, some variability is nevertheless evident in scraper types; single convex side-scrapers dominate, followed by convergent and transverse scrapers. Retouched tools are relatively rare on open-air sites, as well as caves and rockshelters, representing 3\% and more than $7 \%$ of the assemblages, respectively. Additionally, evidence for resharpening and recycling is well represented at both cave and rockshelter sites, with the absence of similar evidence
Flake cleavers were classed according to the technological criteria of J. Tixier (1956; Table 5). Although substantial morphometric variability is evident in each sample, type 0 cleavers (e.g. unmodified, neo-cortical active edges) are most common. ANOVA tests of length to width ratios for samples with more than 20 cleavers demonstrate that, apart from El Castillo and Olha Fi3, there is no statistically significant differences between the different Middle Palaeolithic samples (Fig. 6,1). The largest observed variance (El Castillo and Olha Fi3) concerns only a $0.4 \mathrm{~cm}$ difference in length to width ratios. On the other hand, an initial comparison of late Middle Palaeolithic flake cleavers with an Acheulean sample (data from Benito del Rey, 1983; Mourre, 2003) evinces a statistically significant difference ( $\mathrm{p}<0.01$; Fig. 6,2). While robust differences 
are evident between the two samples, more detailed statistical analysis incorporating flake cleavers found uniquely in the VascoCantabrian region (Montes, 2003) would provide further support for diachronic differences in this tool type. As demonstrated by Iovita and McPherron (2011) for MTA and Acheulean bifaces, it is possible that several orders of differences can be observed amongst the same tool type from different periods. and Arrizabalaga, 2004; Arrizabalaga and Ríos Garaizar, 2012; Álvarez-Alonso, 2014). Recent absolute dates using different methods (Allard, 1993; Cabrera Valdes et al., 1996; Fortea, 1998, 2001; Utrilla, 2000; Saenz de Buruaga and Ebrard, 2004; Mourre et al., 2005, 2006; Bernaldo de Quirós et al., 2006; BarshaySzmidt et al., 2012; Santamaria, 2012; Bernard-Guelle et al., 2014; Colonge et al., 2015) demonstrate these industries to be present

Table 5

Technological classification of studied flake cleavers (After Tixier, 1956).

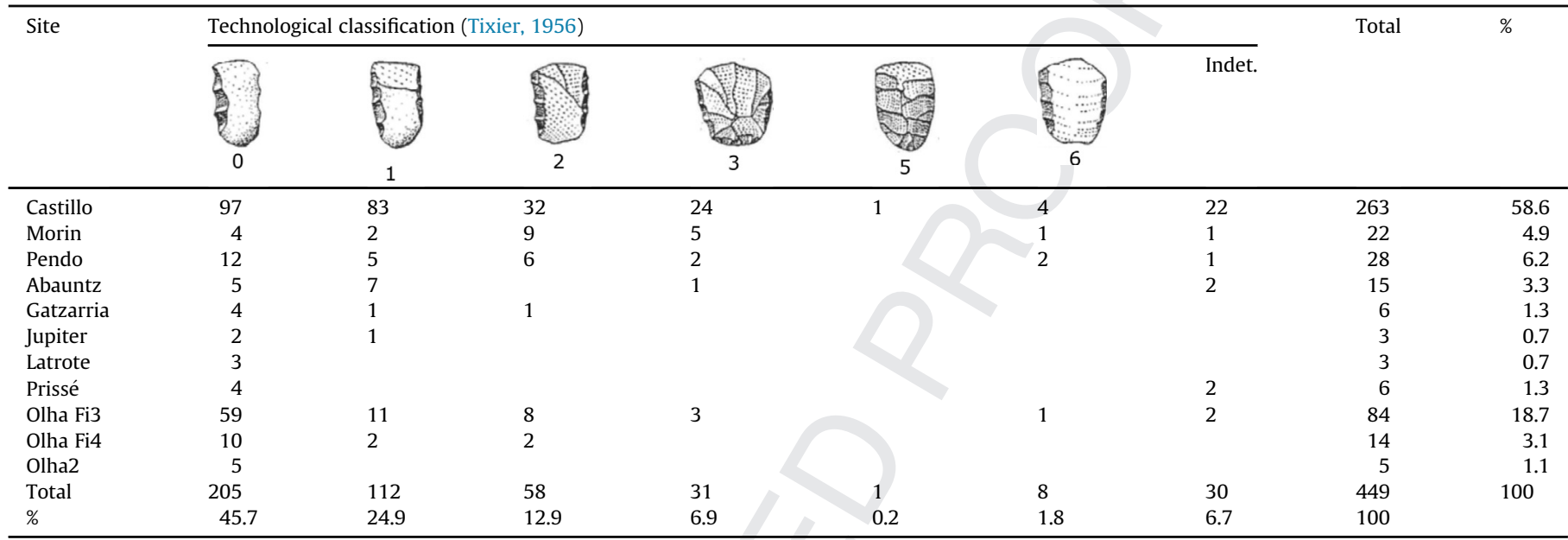

Active edge angles range between 25 and $74^{\circ}$ but cluster around $39-49^{\circ}$. Retouched edges and basal modifications also vary considerably; in the general the base is less frequently retouched compared to the edges and, when the base is retouched, it is often bifacial (see Deschamps, 2014 for more details). These highly flexible modifications are connected to the regularisation of the overall morphology of the pieces for prehension or hafting (Claud et al., 2015).

The particular morphology, size and utilised raw materials make flake cleavers stand out amongst late Middle Palaeolithic retouched tools forms. As such, evaluating functional factors may shed important light on this regionally-specific tool type, especially as macroscopic approaches to quartzite tools are currently unavailable. A series of experiments carried out as part of a collaborative research project (Des Traces et des Hommes, Thiébaut et al., 2009) were designed to test the use of these specific tool forms for processing both vegetal and animal materials using primarily percussive motions (Deschamps et al., 2013; Thiébaut et al., 2014; Claud et al., 2015). The morphology, distribution and termination of the macro-wear present on certain archaeological pieces is consistent with hafted experimental examples used to work hard materials such as wood and bone (Fig. 6,4, see Claud et al., 2015 for more details.) Apart from a single oval biface from La Graulhet (Claud, 2008; Claud et al., 2015) and scrapers from complex G of Sesselfelsgrotte in Germany (Rots, 2009), this type of use has rarely been identified in other late Middle Palaeolithic techno-complexes, possibly suggesting specific use contexts associated with particular environmental conditions.

\section{Discussion}

\subsection{Chronology of Middle Paleolithic industries with flake cleavers}

In addition to the MIS 3 sites discussed here, numerous sites with flake cleavers have been assigned to MIS 5 based on geological or sedimentological evidence (Montes, 2003; Rodríguez Asensio during both MIS 5 and 3 (Fig. 7). Although ten sites are currently dated by different methods (AMS radiocarbon, TL or OSL), those dated uniquely by radiocarbon ought to be considered with some caution as the period in question lies at the very limits of the method (Torre de la et al., 2014). Notwithstanding potential contamination of radiocarbon samples, whether natural or anthropic (Santamaria and de la Rasilla, 2013), late Middle Palaeolithic occupations in the western Pyrenees appear to cluster around $50 \mathrm{ka}$ BP. The fact that recent TL and OSL dates from several open-air sites are consistent with this chronology substantially reinforces placing a part of assemblages containing flake cleavers in MIS 3 around $50 \mathrm{ka}$ cal. BP.

Marine cores from the Bay of Biscay record abrupt climatic changes that correlate with specific Dansgaard-Oeschger (D-O) and Henrich (H) events (Sanchez-Goñi et al., 2008). While it is clear that the Middle Palaeolithic assemblages discussed here date to before the cooler conditions of $\mathrm{H} 5$, current chronological resolution of these strong climatic oscillations unfortunately precludes any more precision. Although varying between sites, available sedimentological, faunal, anthracological and palynological data for the different contexts nevertheless suggest a relatively cool, temperate climate characterised by sparse forests and open environments (e.g. Butzer, 1981; Pike-Tay et al., 1999; Dari and Miskovsky, 2001; Iriarte et al., 2005; Uzquiano, 2005; Sanchez-Goñi and D'Errico, 2005; Sanchez-Goñi et al., 2008). Moreover, rapid changes in Pleistocene ecosystems associated with mountain, littoral and arid zones likely formed a complex environmental mosaic.

Industries containing flake cleavers and bifaces are present during MIS 5 and 3, however, numerous occurrences of these artefact types still lack clear a chronology, as at the cave sites of El Pendo XIII, Morín XV, Amalda VII, Olha Askf1, Isturitz P or the subsurface sites of Lestaulan and Calavanté. New excavations and continued revision of older collections do however allow some potential chronological correlations. For example, at Lestaulan (Chauchat, 1994) comparisons with data from Le Prissé, Jupiter and 


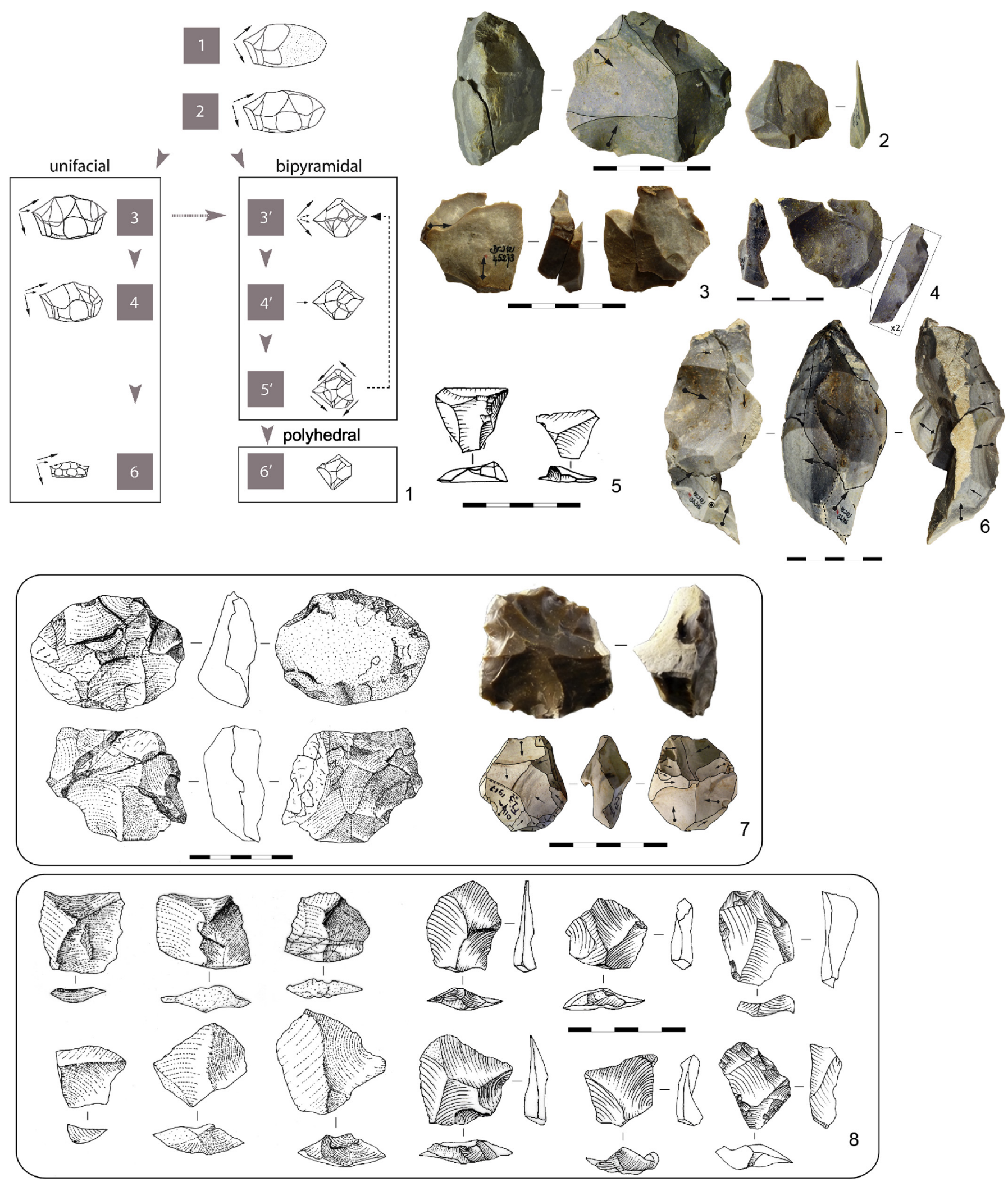

Fig. 3. Discoid debitage. 1: Reduction sequence from the open-air sites of Prissé, Jupiter and Latrote. 2, 3, 6: Refits from Prissé and Jupiter. 4, 5: Pseudo-Levallois points. 7: Centripetal Discoid cores from Gatzarria, Olha and Latrote. 8: Centripetal flakes and pseudo-Levallois points from Gatzarria and Olha. 

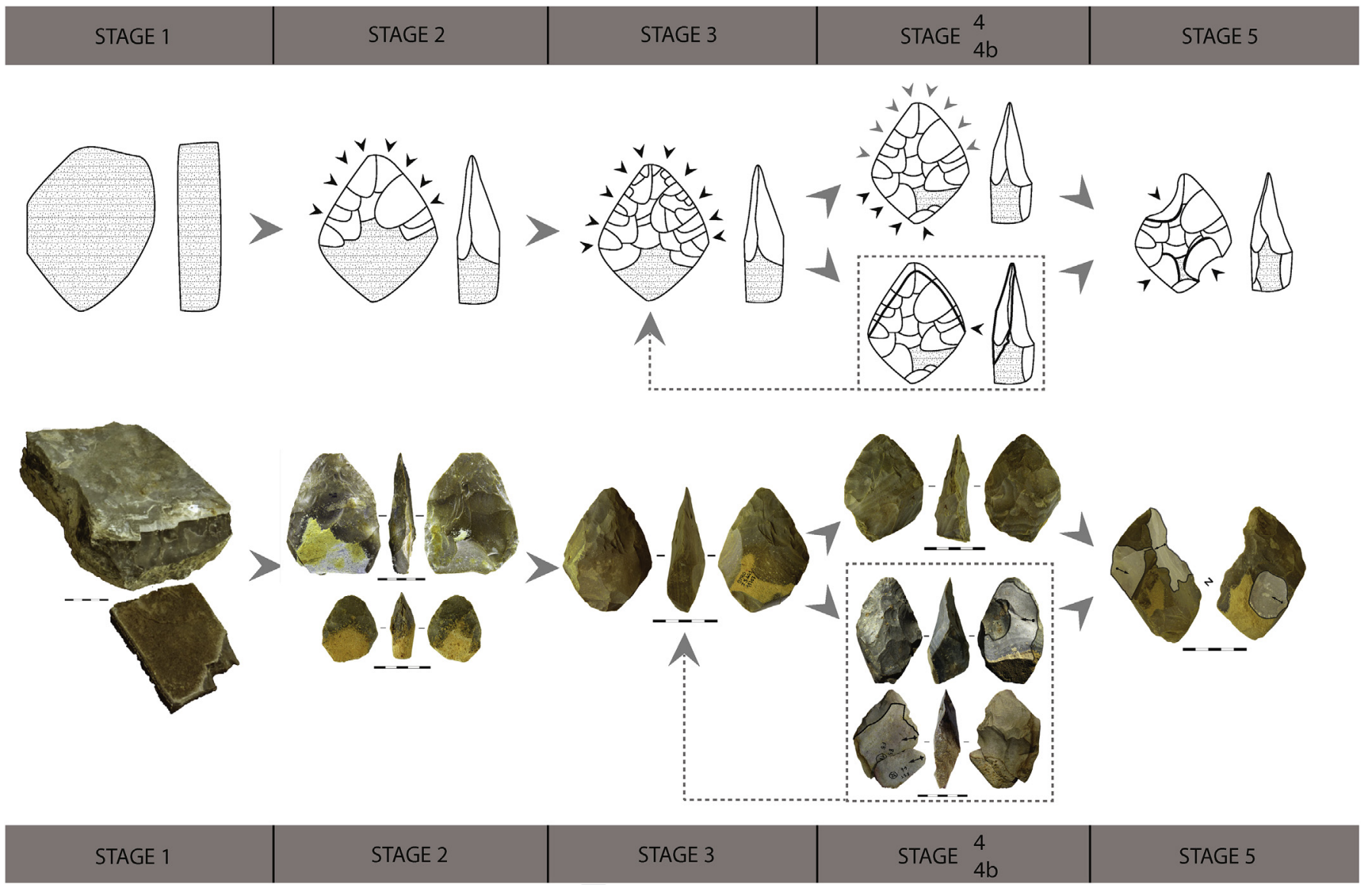

Fig. 4. Regional bifacial shaping sequence.

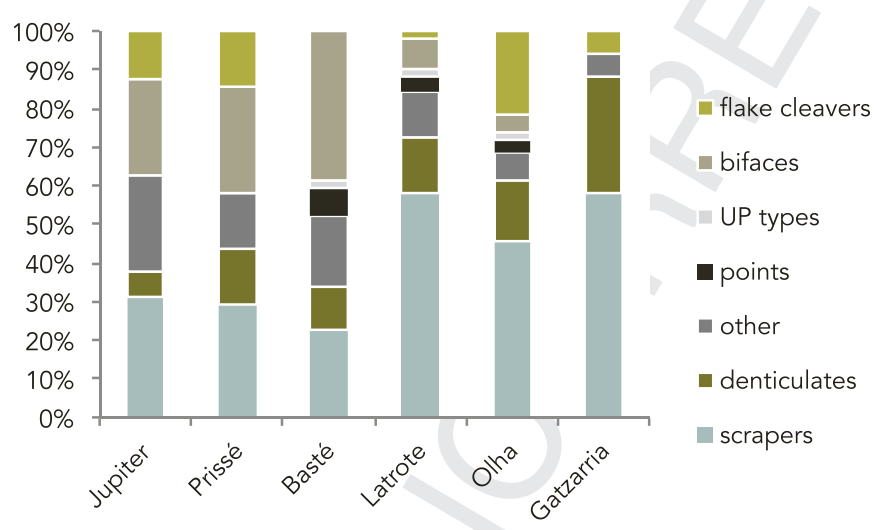

Fig. 5. Percentage of retouched tools by site.

Le Basté may shed light on the chrono-stratigraphic position of this surface collection. At Olha, while Discoid and Levallois technologies coexist, the heavily reduced nature of the assemblage, including intense tool resharpening, suggest a particular economical profile, thus complicating any chronological correlations.

\subsection{Regional synchronic comparisons}

Several sites in the southern Basque Country, Cantabria and Asturias have produced assemblages dated to MIS 3 that include a flake cleaver component. The rich faunal assemblage of level $\mathrm{H}$ at
Abauntz dominated by bear remains (Mazo et al., 2011-12), is associated with a small lithic assemblage ( $<50$ pieces) including several bifaces and flake cleavers. However, the small size of the assemblage precludes evaluating associated flake production methods and intrusive elements from the overlying Upper Palaeolithic levels cannot be ruled out (Utrilla, 2000), suggesting the partial reworking of this level.

At Amalda (layer VII), the centripetal recurrent Levallois method on flint is best represented and coexists with flakes attributable to the Quina concept (Ríos, 2012). Discoid debitage concerns primarily non-flint raw materials and is principally geared around the production of pseudo-Levallois points. In terms of retouched tools, scrapers are most common, including several Quina types, followed by denticulates. Several bifaces or bifacial preforms are also present, all with cortical bases. Finally, while "large cutting tools" are present, the published examples are not genuine flake cleavers according to the definition of J. Tixier (1956). Considerable postdepositional processes affecting layers VI and VII at Amalda (Yravedra, 2007; Ríos-Garaizar, 2012) equally suggests caution in terms the integrity of the assemblage. While no information is currently available concerning the technology of layer 15 at Cueva Morín, a recent technological revision of layers 16 to 18 (Lazuén, 2012) placed both assemblages in MIS 4. However, the lack of detailed recent analysis for levels 13 to 15 of Cueva Morin makes any comparison impossible.

Recent work with the material from layer 20e of El Castillo demonstrated a Discoid (both unifacial and bifacial) dominated assemblage alongside a much rarer Levallois component (Sanchez Fernández and Bernaldo de Quiros, 2008). Scrapers are the most 

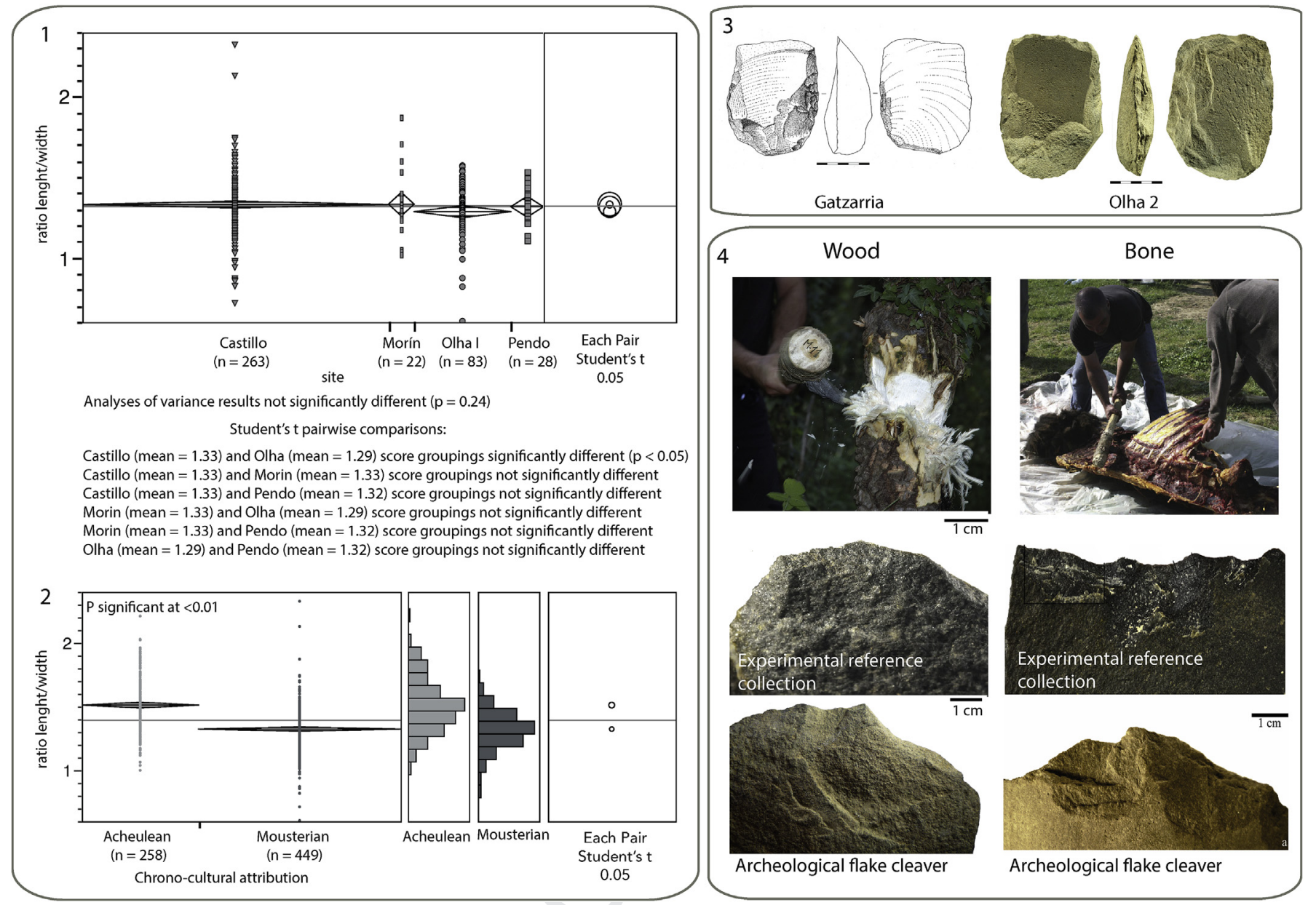

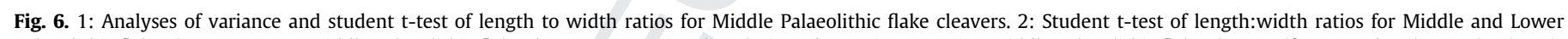

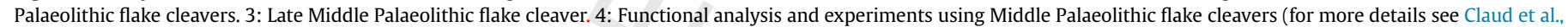
2015).

common retouched tools followed by denticulates. Several scrapers with Quina retouch and other tools types are also present, as are type 0 flake cleavers in ophite or quartzite. The fact that level 20e lies between two nearly sterile levels suggest a good degree of taphonomic integrity.

A recent analysis of level XIII-base at the Viña rochshelter revealed Discoid and Levallois methods on quartzite geared around the alternate production of éclats débordants and flakes with peripheral edges (Santamaria, 2012) to coexist in the assemblage, although the Levallois method appears more frequent. This level is unique at the site as it contains both bifaces and flake cleavers. Like Amalda VII, Cueva Morin 15 and Bolomor III, scrapers dominate followed by denticulates. Finally, several intrusive elements from the site's Aurignacian levels also identified (Santamaria, 2012).

Other late Middle Palaeolithic sites with flake cleavers derive, unfortunately, from disturbed contexts and or old excavations (e.g. Kurtzia or Isturitz). Flake cleavers and bifaces are not systematically present in secure MIS 3 contexts. For example, they are absent in assemblages assigned to the Quina techno-complex and are notably missing from layers XI to XVI at Esquilleau, levels J and K of Covalejos, and layers B and D of Axlor (Baena et al., 2005; Sanguino and Montes, 2005; Ríos-Garaizar, 2012). Moreover, at Gatzarria, an ongoing taphonomic analysis demonstrated the reported Quina industry at the back of the cave to contain a stratigraphic mix of material from the underlying layer, ruling out any association of this industry with flake cleavers at this site (Deschamps, 2014). Similarly, these tool types are consistently absent in late Middle Paleolithic Discoid-denticulate assemblages, as at Flecha Cave, layers 11 and 12 of El Pendo, layers 11 and 12 of Cueva Morin and layers VI and VII of Esquilleu (Freeman and Gonzàlez Echegaray, 1967; Gonzàlez Echegaray and Freeman, 1971; Baena et al., 2005; Thiébaut, 2005).

Finally, the fact that flake cleavers are not associated with all late Middle Palaeolithic assemblages types in the region but rather with those portraying particular typo-technological characteristics suggests the existence of a Discoid lithic techno-complex (TCL) with flake cleavers and bifaces during the MIS 3. While still controversial and in order to avoid introducing new terms, the designation 'Vasconian' has been nevertheless been retained to describe this assemblages. This techno-complex most often contains only a minor Levallois component and is associated primarily with scrapers followed by notches and denticulates as well as flake cleavers and bifaces in the assemblages studied here. Despite these shared characteristics a certain degree of variability is nevertheless evident, particularly in terms of retouched tools, which can vary significantly and is likely connected to different site functions (i.e. habitation versus production sites). Moreover, raw material exploitation patterns seem to reveal a shared and relatively well-defined and structured territory, at least north to east, which is set apart from contemporaneous MTA occurences in 


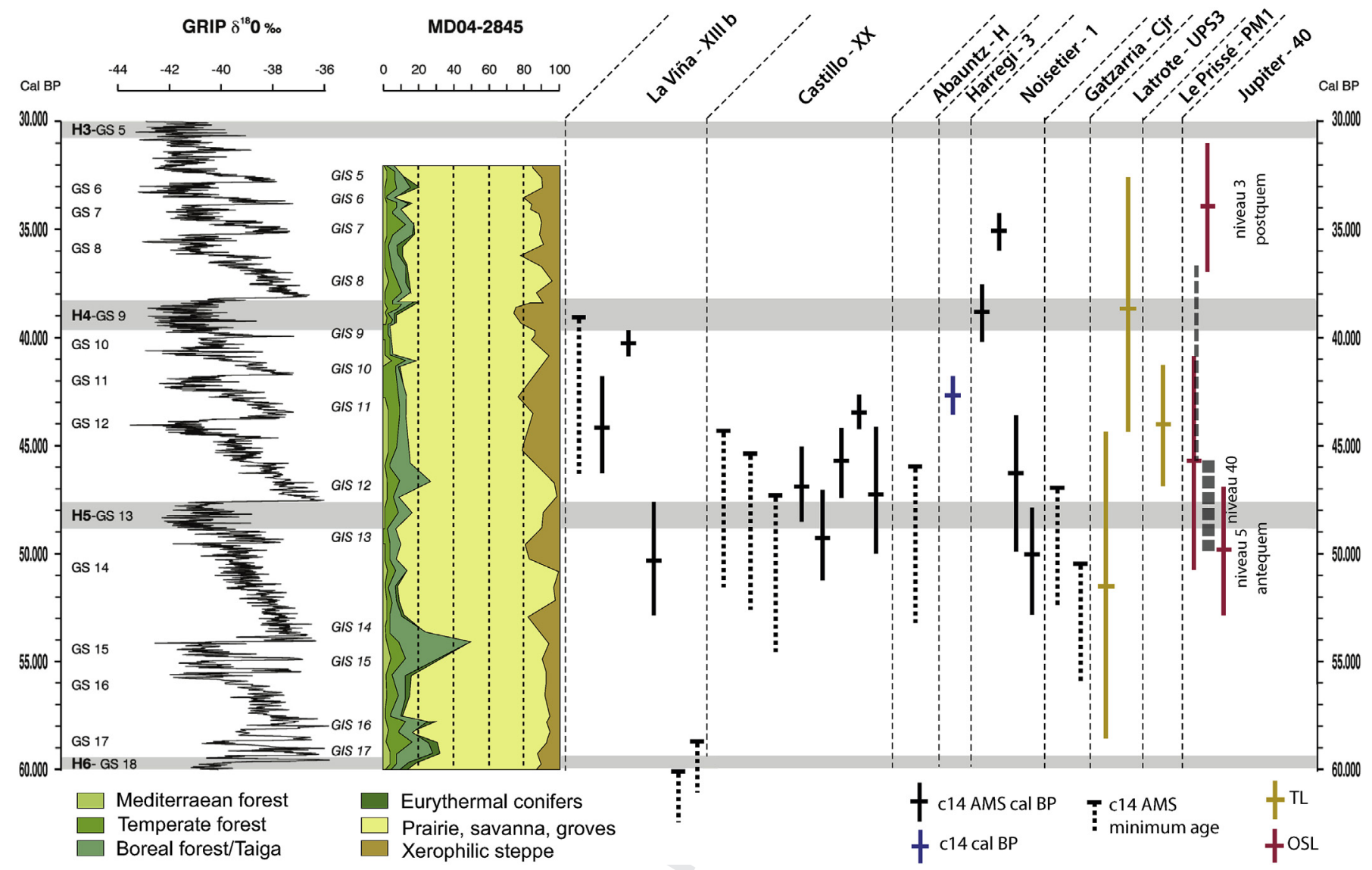

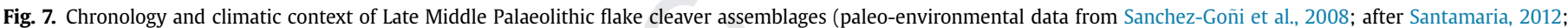
modified).

the northern Aquitaine Basin. Interpreting similarities and differences between these two techno-complexes as a reflection of either assemblage variability or cultural diversity, however, remains an open question.

\subsection{Inter-regional comparison}

Comparing typo-technological aspects of contemporaneous lithic techno-complexes may reveal certain particularities specific to the Vasconian. Several European techno-complexes dated to MIS 3 have been identified based on the morphology of their bifacial tool component: the MTA (Peyrony, 1920; Bordes, 1950; Soressi, 2002), the Keilmessergrüppen or KMG (Jöris, 2004, 2006) and industries with 'bout-coupés' forms (White and Jacobi, 2002; Wragg Sykes, 2009; Ruebens and Wragg-Sykes, in press). The MTA is characterised primarily by cordiform and triangular bifaces (Soressi, 2002; Ruebens, 2012), while the KMG, although still containing cordiform bifaces, is best typified by asymmetric backed bifaces (Keilmesser) with a convex active edge (Bosinski, 1967; Jöris, 2004). The 'bout-coupés' group, which again contains a cordiform biface component, is best characterised by flat-butted cordate forms (or bout-coupés) that are generally widest at the base and entirely shaped (Ruebens and Wragg-Sykes, in press). While the MTA and KMG appear relatively well-defined geographically, others remain problematic. This is especially the case with the Mousterian with bifacial tools or MBT. This term, originally applied to Middle Palaeolithique assemblages from the Armorican Massif (Molines et al., 2001; Bourdin, 2006), groups assemblages with no clear chronological framework other than dating to between MIS 5 and 3. Saint-Brice-sous-Rânes was the first directly dated site in the region with a defined stratigraphic context (Cliquet et al., 2009). Attributed to the final Mousterian, this assemblage has been compared with the late Middle Palaeolithicto-Upper Paleolithic foliate point phenomenon in Central Europe.

Recently, a new hypothesis proposed that, given the imprecise chronology (MIS 5 to 3 ) for most sites in northern and western France, these assemblages should be grouped under the generic term "Mousterian with bifacial tools" or MBT (Ruebens, 2012, 2013, 2014), which is spread across a large area of northern and central France and comprises different forms of bifacial tools. Variability in bifacial tools forms found within this extensive area has also been interpreted as reflecting eastern (KMG) and southern (MTA) influences (Ruebens, 2013, 2014). Unfortunately, the lack of reliable, taphonomically tested data reveals the definition of the MBT as conceived by Ruebens not take into account possible chronological, geographic or functional variations in these assemblages.

Vasconian bifacial tools most often retain a cortical base and are lozenge-shaped. And, although cordiform examples do exist, they are produced following a different chaîne opératoire than examples from MTA contexts in the northern Aquitaine Basin. Morphological similarities are more related to convergences connected to the successive resharpening and rejuvenation of Vasconian cordiform bifaces rather than a genuine desire to impose this form. Moreover, the base of most MTA bifaces, whether cordiform or triangular, is entirely shaped before the symmetric edges and point are finished. An examination of available 
reduction sequences (Claud, 2008) suggests the shaping of the base to be an integral part of the MTA chaîne opératoire. Even if MTA examples with partially cortical bases are known, as at Le Moustier for example, they nevertheless portray evidence of some form of basal shaping (Soressi, 2002), marking clear differences between Vasconian and MTA bifacial tools. Moreover, stark contrasts between both production methods and the preferential use of particular raw materials are also evident between Vasconian flake cleavers and associated bifacial tools. Flake cleavers are manufactured almost uniquely on quartzite and ophite, further reinforcing the regional specificity of this tool type that has no functional equivalent in other contemporaneous industries.

While these various bifacial tools appear to reflect geographically concentrated types, satisfactorily characterising regional techno-complexes based on a single element of a more general technological system remains difficult (e.g. Ruebens, 2014). Instead, incorporating elements related to raw material procurement patterns, flake production methods, the transformation and resharpening of tools, and the fragmentation of the chaine opératoire provide a fuller, more comparable vision of the overall technological system than does a reliance solely on 'fossil directors'. The MTA is most commonly associated with Levallois debitage and the production of elongated flakes (Soressi, 1997, 2002 and references therein; Turq, 2000; Jaubert, 2013), although the Discoid method is present, it is less frequent. However, as a majority of research concerning the MTA has focused on characterising its bifacial component, the variability of associated flake production methods and the general techno-economic coherency of this technocomplex remains under-evaluated (Gravina and Discamps, 2015). The KMG is equally typified by the Levallois method, particularly centripetal and blade modalities (Jöris, 2004; Richter, 2006). On the other hand, like 'bout coupés' assemblages in Great Britain (Wragg

Q2 Sykes, 2009; White and Pettitt, 2011; Ruebens et al., 2015), the Discoid method is best represented in western Pyrenees and is only associated with what remains a minor Levallois component. Differences in the technological composition of these assemblages most likely reflect techno-economic considerations and contingencies, including the preferential selection of specific raw materials and the spatio-temporal fragmentation of the chaine opératoire. Currently, gross-grain characterisations of the large majority of these assemblages unfortunately complicate muchneeded, detailed inter-regional comparisons both in terms production objectives and their diversity.

Differences between these techno-complexes are also perceptible in the proportion of retouched tool forms, although side scrapers and denticulates remain the most common tool types. Variable proportions of backed knives and Upper Palaeolithic tool types are generally found associated with side scrapers in certain MTA assemblages (Soressi, 2002; Ruebens and Wragg-Sykes, in

Q3 press), while Upper Palaeolithic tool forms accompany a dominant scraper and denticulate component in the KMG. Upper Palaeolithic types and points are rare or absent in Vasconian assemblages, which are dominated by scrapers but that nevertheless contain a considerable denticulate and notched tool component. Similarly, the retouched tool component of British 'bouts-coupés' assemblages are primarily composed scrapers, notches and denticulates (Ruebens et al., 2015). Interpreting differences in the retouched tool components of these techno-complexes is unfortunately hampered by the lack of more nuanced analyses focusing on, for example, blank selection, working edge angles, or functional and specific patterns of tool resharpening and reduction as a function of raw material. Likewise, the broad-scale incorporation of use-wear studies and the integration of small finds (e.g. retouch or rejuvenation flakes) in technological analysis will undoubtedly produce complementary data for comparing these assemblage types.

\subsection{Regional techno-complexes}

Continued comparison of MIS 3 techno-complexes reveals clear regional patterns (Fig. 8) during the late Middle Palaeolithic of Western Europe (Turq et al., 1990; Palma di Cesnola, 1996; Bourguignon, 1997; Finlayson et al., 1998; Slimak, 2001; Soressi, 2002; Jöris, 2004; Porraz, 2005; Richter, 2006; Zilhão, 2006; Zilhão and Villaverde, 2008; Wragg Sykes, 2010; Lebègue, 2012; Thiébaut et al., 2012; Ruebens, 2013; Eixea et al., 2014). Certain techno-complexes are relatively well-defined geographically and chronologically. This is particularly the case with the MTA, which benefits from numerous absolute dates (Valladas et al., 1986; Guibert et al., 2008; Vieillevigne et al., 2008; Richter et al., 2013) and archeo-stratigraphic evidence (Jaubert, 2013) placing it to between 50 and $45 \mathrm{ka}$ BP. Assemblages containing 'bout-coupés' forms are similarly dated by several methods to roughly the same period between 50 and $35 \mathrm{ka} \mathrm{BP}$ (White and Pettitt, 2002; Ruebens et al., 2015). The chronology of the KMG is, on the other hand, slightly less straightforward. The final MIS 3 phase of this technocomplex is known from only a small number of sites with reliable absolute dates, with the exception of layer 7a at Külna and the G complex of Sesselfelsgrotte (Richter et al., 2000; Jöris, 2006). On the other hand, the Vasconian industries of the southern Aquitaine Basin can be seen as a typo-technologically and chronologically coherent entity whose most eastern and northern limits are represented, respectively, by layer 1 of Noisetier Cave and the open-air site of Latrote.

One hypothesis contends that the diversity of bifacial tool forms found across northern Europe from Belgium to the Amorican Massif and as far south as the Loire Valley reflects the changing demography and or interaction of MTA and KMG groups (Ruebens, 2012, 2013). However, this 'entity' is defined almost exclusively on tool morphology, somewhat downplaying the influence of raw materials (i.e. availability and quality), manufacturing methods and the overall technological system. An alternative, chronological model accounting for the demographic dynamics of northern France has recently been proposed by Locht and Depaepe (2015). According to this model, the region's MIS 3 archaeological record would reflect a recolonisation event during a period of climatic amelioration by human groups unrelated to those who occupied the same region during MIS 5. Similarities between MIS 3 bifaces from northern France and those recovered from MTA contexts are taken to reflect the postMIS 4 movement of groups northwards. These differing hypotheses accounting for the distribution of bifacial tool forms once again highlights the necessity of further refining their chronostratigraphic context.

At the larger scale of Western Europe, techno-complexes with evidence for macro-tools are present in northern and western areas and absent from more eastern and southern regions. Several zones to the south and east of the Massif Central may also have evidence for coherent assemblages that may be considered regional techno-complexes. Although attributed to MIS 3, numerous sites still lack absolute chronologies, complicating establishing their contemporaneity. This is particularly the case for the Rhodanian Quina and the Middle Palaeolithic of the Languedoc and Liguro-Provencal regions (Slimak, 2001; Porraz, 2005; Lebègue and Wengler, 2014). The distribution of industries associated with macro-tools may correlate with palaeoanthopological data and recent genetic work focusing on Neanderthal demographics that revealed differences between eastern and western Neanderthal populations and evidence for a third more southern group (Fabre et al., 2009). In material culture terms, the line separating northern and southern Neanderthals populations corresponds almost perfectly to the distribution of European industries with and 


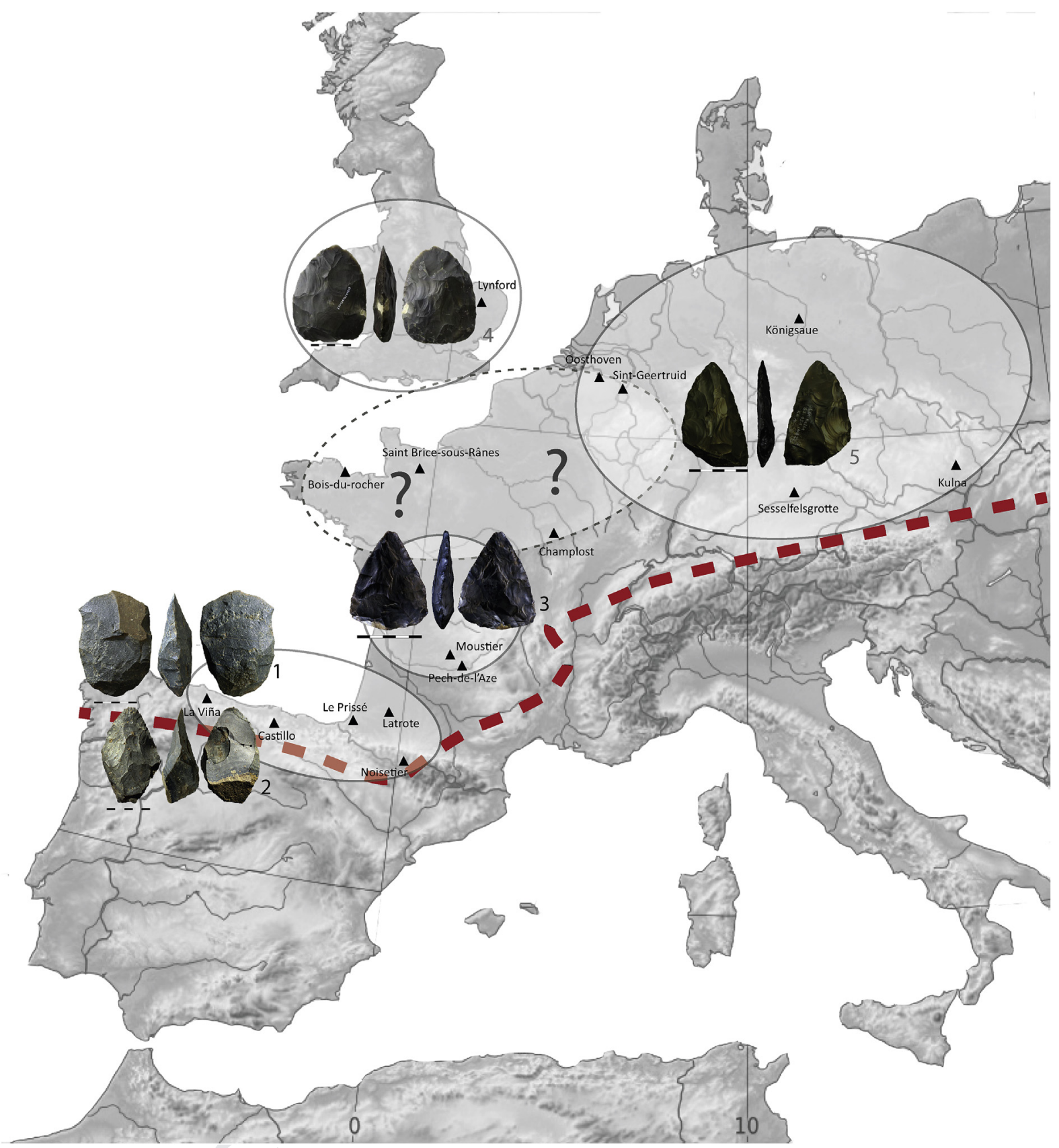

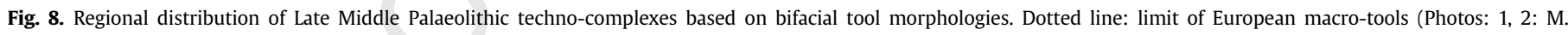
Deschamps; 3: Soressi, 2002; 4: Wragg Sykes, 2009; 5: Ruebens, 2012).

without macro-tools. Whether differences between regional entities with macro-tools (e.g. the Vasconian, MTA, KMG, boutcoupés) equally reflect the genetic variability of Neanderthal populations remains to be tested.

\section{Conclusion}

The techno-typological analysis of a group of sites in the southern Aquitaine Basin provides a much more detailed characterisation of the region's late Middle Palaeolithic industries than was previously possible. In order to better compare contemporaneous industries with a bifacial component, such as the MTA, KMG, or 'bout-coupés' assemblages, future collaborations should concentrate on developing multidisciplinary approaches incorporating taphonomic, petrographic, typological, use-wear, spatial, zooarchaeological and palaeoenvironmental approaches in order to refine our understanding of the socio-economy and mobility strategies of late Middle Palaeolithic populations. By the same token, addressing late Middle Palaeolithic cultural geography in Western Europe at different analytical scales (e.g. topography, resource availability and distribution) is essential for elucidating how particular human groups adapted their mobility strategies to exploit a given territory and interpreting differences in these patterns between regions (Roebroeks, 1988; Féblot-Augustins, 1993; Gamble, 1993; Turq et al., 2013).

Finally, clarifying the nature of this regionalisation of technological traditions will inevitably produce a more robust understanding of the emergence of the Upper Palaeolithic as well as the 
probable mechanisms underlying the eventual disappearance of the Neanderthals. However, focusing uniquely on the MIS 3 archaeological record is insufficient for understanding underlying anthropological processes. This apparent regionalisation may reflect changes in MIS 3 Neanderthal societies or result from a process that began in MIS 5 .

\section{Uncited reference}

\section{Álvarez-Alonso et al., 2014, Thibault, 1970.}

\section{Acknowledgements}

I would like to thank the editors of this special volume, J.-Ph. Faivre, E. Discamps, A. Turq and B. Gravina, for inviting me to participate. I am grateful for the support of the UMR 5608 TRACES, University of Toulouse, particularly the SMP3C team and its directors, S. Costamagno and N. Teyssandier, for assuring financial support for the translation of this article. The work presented here was carried out as part of doctoral research directed by F. Bon and V. Mourre, both of whom are warmly thanked. The writing of this article was made possible by a grant from the Treilles Foundation (Prix Jeune Chercheuse) in 2015 and support from the research project "Des traces et des hommes", especially C. Thiébaut, É. Claud and S. Costamagno. The Inrap provided financial support for the study of the Prissé and Chemin de Jupiter material. I would like to thank Olivier Ferullo, Nathalie Fourment, Jean-Jacques Cleyet-Merle, David Colonge, Sébastien Bernard-Guelle and Odile Romain for granting me access to different collections. Finally, I would like to thank Brad Gravina and the anonymous reviewers whose constructive comments helped improve the text.

\section{References}

Allard, M., 1993. Fréchet-Aure, Grotte du Noisetier, Bilan scientifique 1992 de la Direction Régionale des Affaires Culturelles de Midi-Pyrénées. Ministère de la Culture, pp. 113-114.

Álvarez-Alonso, D., 2012. El primer poblamiento humano en la región cantábrica. Reflexiones y sínthesis en torno al paleolítico antiguo. Kobie Serie Paleoantropologia 31, 21-44.

Álvarez-Alonso, D. 2014. First Neanderthal settlements in northern Iberia: the Acheulean and the emergence of Mousterian technology in the Cantabrian region. Quaternary International 326-327, 288-306.

Álvarez-Alonso, E., Rodríguez Asensio, J., Jordà Pardo, J., 2014. Reflexiones en torno a la caracterisación tecnotipológica del yacimiento de Bañugues (Asturias, España) en el marco del Paleolítico medio del norte de la Península Ibérica. Munibe 65, 5-24.

Arrizabalaga Valbuena, A., Ríos Garaizar, J., 2012. The first human occupation of the Basque crossroads,. Journal of World Prehistory 25, 157-181.

Baena, J., Carrion, E., Ruiz, B., Ellwood, B., Sesé, C., Yravedra, J., Jordà, J., Uzquiano Ollero, P., Velazquez, R., Manzano, I., Sanchez-Marco, A., Hernandez, F., 2005. Paleoecología y comportamiento humano durante en la comarca de Liébana: la secuencia de Esquilleu (Occidente de Cantabria, España). In: Montes Barquín, R., Lasheras, J. (Eds.), Neandertalos cantábricos, estado de la cuestión, Monografías 20. Museo nacional y centro de Investigación de Altamira, Santander, pp. $461-487$

Baldeon, A., 1990. El Paleolítico Inferior y Medio en el País Vasco. Una aproximacion en 1990. Munibe 42, 11-22.

Barshay-Szmidt, C., Eizenberg, L., Deschamps, M., 2012. Radiocarbon (AMS) dating the classic aurignacian, Proto-Aurignacian and vasconian mousterian at gatzarria cave (Pyrénées-atlantiques, France). Paléo 23, 11-38.

Benito del Rey, L., 1972-73. Los hendidores de la capa musteriense "Alfa" de la Cueva del Castillo (Santander). Estudio tipológico, Zephyrus XXIII-XXIV, 269-290.

Benito del Rey, L., 1976. La industria lítica musteriense de la capa "alfa" de la Cueva del Castillo (Puente Viesgo, Santander). Zephyrus XXVI-XXVII, 31-84.

Benito del Rey, L., 1979. Transformation de hachereaux en galets aménagés dans les niveaux du Moustérien avec hachereaux des grottes du Castillo, de "El Pendo", et, au moins dans quelques niveaux de la grotte Morín (Prov. de Santander). L'Anthropologie 83 (4), 547-555.

Benito del Rey, L., 1981. Aspectos técnicos y typológicos que relacionan estrechamente el Musteriense con hendidores de las cuevas del Castillo y Morín (Santander). Munibe 33 (3-4), 157-170.
Benito del Rey, L., 1983. Convergencias y divergencias técnicas y morfológicas entre dos colecciones de hendidores: una achelense y otra musteriense, O Arqueólogo Português. Série IV 1, 39-62.

Bernaldo de Quirós, F., Cabrera Valdès, V., Stuart, J., 2006. Nuevas dataciones para el Musteriense y el Magdaleniense de la cueva de El Castillo. In: Cabrera Valdès, V., Bernaldo de Quirós, F., Maíllo Fernández, J.M. (Eds.), En el centenario de la cueva del Castillo: El ocaso de los Neandertales, centro asociado a la UNED en Cantabria, pp. 453-457.

Bernard-Guelle, S., Rué, M., Fernandes, P., Coudenneau, A., Courty, M.-A., Fedoroff, N., Dawson, M.-C., Tacussel, P., Séronie-Vivien, M., Séronie-Vivien, M.R., 2010. Le site Paléolithique moyen de Latrote (Saint-Gein, Landes). Rapport final d'opération. Paléotime, p. 542.

Bernard-Guelle, S., Rué, M., Fernandes, P., Coudenneau, A., Fedoroff, N., Courty, M.A., Séronie-Vivien, M., Dawson, M.-C., Picavet, R., Airvaux, J., 2014. Comportements techniques et stratégies de subsistance sur le site moustérien de plein air de Latrote (Saint-Gein, Landes). In: Thiébaut, C., Claud, E., Costamagno, S. (Eds.), Exploitation des ressources organiques à la fin du Paléolithique moyen et au début du Paléolithique supérieur: interactions entre environnement et comportements techniques, XXVIIe congrès préhistorique de France, session E, Bordeaux - Les Eyzies 31 mai-5 juin 2010, pp. 229-256

Boëda, E., 1988. Le concept Levallois et évaluation de son champ d'application. In: Binford, L., Rigaud, J.-P. (Eds.), L'Homme de Néandertal, La Technique, ERAUL 31, vol. 4, pp. 13-26. Liège.

Boëda, E., 1993. Le débitage Discoïde et le débitage Levallois récurrent centripète. Bulletin de la Société Préhistorique Française 90 (6), 392-404.

Boëda, E., 1994. Le concept Levallois: variabilité des méthodes. CNRS, monographie du CRA n ${ }^{\circ}$ 9, Paris, p. 280.

Bon, F., coll, Chauvaud, D., Dartiguepeyrou, S., Gardère, P., Klaric, L., Mensan, R., 2002. Les ressources en silex e la chalosse centrale: gîtes et ateliesrs du dôme diapir de Bastennes-Gaujacq et de l'anticlinal d'Audignon. In: Cazals, N. (Ed.), Comportements techniques et économiques des sociétés du Paléolithique supérieur dans le contexte pyrénéen, projet collectif de recherche service régional de l'archéologie Midi-Pyrénées, pp. 47-63.

Bordes, F., 1950. L'évolution buissonnante des industries en Europe occidentale. Considération théoriques sur le Paléolithique ancien et moyen. L'Anthropologie 54, 393-420.

Bordes, F., 1953. Essai de classification des industries "moustériennes". Bulletin de la Société Préhistorique Française 457-466 n 7-8.

Bordes, J.-G., 2002. Les interstratifications Châtelperronien/Aurignacien du Roc-deCombe et du Piage (Lot, France). Analyse taphonomique des industries lithiques; implications archéologiques. Thèse de doctorat. Université de Bordeaux 1, p. 365.

Bosinski, G., 1967. Die mittelpaläolithischen Funde im westlichen Mitteleuropa, Fundamenta A/4. Böhlau-Verlag, Köln and Graz.

Bourdin, S., 2006. Le Moustérien à outils bifaciaux du Massif armoricain au Pléistocène récent dans son contexte européen: vers la définitions d'un faciès régional (Ph.D. dissertation). Université de Rennes.

Bourguignon, L., 1997. Le Moustérien de type Quina: nouvelle définition d'une entité technique (Thèse de doctorat). Université de Paris X - Nanterre, p. 672.

Bourguignon, L., Turq, A., 2003. Une chaîne opératoire de débitage Discoïde sur éclat du Moustérien à Denticulés aquitain: les exemples de Champ de Bossuet et de Combe-Grenal c. 14. In: Peresani, M. (Ed.), Discoid Lithic Technology - Advances and Implications, BAR International Series 1120. Oxford, pp. $131-152$.

Bourguignon, L., Brenet, M., Folgado, M., Ortega, I., 2011. Aproximación tecnoeconómica del debitage discoide de puntas pseudo-levallois: el aporte de la experimentación. In: 2nd Congreso Internacional de arqueologia experimental, pp. 53-59.

Bruxelles, L., Jarry, M., Servelle, C., 2012. Ressources lithiques des formations alluviales du midi toulousain: Méthodologie, résultats et premières applications aux séries paléolithiques. In: Marchand, G., Querré, G. (Eds.), Roches et sociétés de le Préhistoire: entre massifs cristallins et bassins sédimentaires, 28-30 avril 2010. Presses Universitaires de Rennes, pp. 31-49.

Butzer, K., 1981. Cave sediments, upper Pleistocene stratigraphy and Mousterian facies in cantabrian Spain. Journal of Archaeological Science 8, 133-183.

Cabrera Valdès, V., 1983. Notas sobre el Musteriense cantábrico: el "Vasconiense", Homenaje al Prof. Martín Almagro Basch, I. Ministerio de Cultura, Madrid, pp. 131-141.

Cabrera Valdes, V., 1984. El yacimiento de la cueva del Castillo (Puente Viesgo, Santander), Bibliotheca Praehistorica Hispana. Santander XXII, 485.

Cabrera Valdes, V., Bernaldo de Quirós, F., Hoyos Gomez, M., 1996. Hugo Obermaier y la cueva del Castillo, "El hombre fósil": 80 anos después. Universidad de Cantabria Fundacion Marcelino Botin Institute for Prehistoric Investigations.

Cahen, D., Moeyersons, J., 1977. Subsurface movements of stone artifacts and their implications for the prehistory of Central Africa. Nature 266, 117-123.

Carrión Santafé, E., Baena, J., Conde, C., Cuartero, F., Roca, M., 2008. Variabilidad tecnológica en el musteriense de Cantabria. Treball's d'Arqueologia 14, 279-318.

Carrión Santafé, H., 2003. Variabilidad tecnica en el Musteriense de Cantabria. Universidad Autónoma de Madrid, Colección tesis en microficha, p. 1305.

Charpentier, V., 1999. Industries bifaciales holocène d'Arabie orientale, un exemple: Ra's al-Jinz, 32nd meeting of the seminar for arabian study, Londres. 16-18 juillet 1998 (29), 29-44

Chauchat, C., 1985. L'abri Olha (Pyr. Atl.) - la nouvelle étude de la collection Passemard. Bulletin de la Société Préhistorique Française 82, 237-238. 
Chauchat, C., 1986. Théorie et pratiques dans la Préhistoire du Pays Basque. Bulletin de la Société Préhistorique Française 83 (7), 197-200.

Chauchat, C., 1994. La station préhistorique de Lestaulan, quartier de Maignon, à Bayonne (Pyrénées-atlantiques). Munibe 46, 3-22.

Chauchat, C., Thibault, C., 1968. La station de plein air du Basté, à Saint-Pierre d'Irube (Basses - Pyrénées). Géologie. Etude archéologique préliminaire. Bulletin de la Société Préhistorique Française 75 (10), 314-326.

Clark, A.-E., 2015. Spatial Structure and the Temporality of Assemblage Formation: a Comparative Study of Seven Open Air Sites in France (PhD thesis). University of Arizona.

Claud, É., 2008. Le statut fonctionnel des bifaces au Paléolithique moyen récent dans le sud-ouest de la France. Thèse de doctorat. Université de Bordeaux 1 , p. 546.

Claud, É., Deschamps, M., Colonge, D., Mourre, V., Thiébaut, C., 2015. Experimental and functional analysis of late Middle Paleolithic cleavers in southwestern Europe (France and Spain). Journal of Archaeological Science 62, 105-127.

Cliquet, D., Mercier, N., Lautridou, J.-P., Beugnier, V., Bianchini, R., Caspar, J.-P. Coutard, S., Lasseur, E., Lorren, E., Gosselin, R., Rivard, J.-J., Valladas, H., 2009. Un atelier de production et de consommation d'outils bifaciaux de la fin du Paléolithique moyen à Saint-Brice-sous-Rânes (Orne, France) dans son contexte environnemental. Quaternaire 20 (3), 361-379.

Colonge, D., Chalard, P., Bilotte, M., Ducasse, S., Platel, J.-P., 2011. Nouvelle découverte d'un gîte à silex à Lepidorbitoïdes dans le Sud-Ouest de la France (Saint-Aubin, Gers) et implications archéologiques. Bulletin de la Société Préhistorique Française 108 (3), 561-578.

Colonge, D., Claud, E., Deschamps, M., Fourloubey, C., Hernandez, M., Sellami, F., Anderson, L., Busseuil, N., Debenham, N., Garon, H., O'Farell, M., 2015. Preliminary results from New Palaeolithic open-air sites near Bayonne (southwestern France). Quaternary International 364, 109-125.

Colonge, D., Hernandez, M., Lelouvier, L.-A., Mercier, N., Mourre, V., Busseuil, N., 2014. Paléolithique ancien et Paléolithique moyen ancien dans le piémont pyrénéen occidental: relations entre chaînes opératoires, continuités et ruptures. In: Brenet, M., Bourguignon, L., Jarry, M. (Eds.), Émergence et diversité des techno-complexes au Paléolithique moyen ancien. Relations entre productionde débitage et de façonnage, XXVIIe congrès préhistorique de France, session C, Bordeaux - Les Eyzies 31 mai-5 juin 2010, pp. 119-138.

Dari, A., Renault-Miskovsky, J., 2001. Etudes paléoenvironnementales dans la grotte "El Castillo" (Puente Viesgo, Cantabrie, Espagne), Espacio. Tiempo y Forma 14, 121-144.

Deschamps, M., 2014. La diversité culturelle au Paléolithique moyen récent: le Vasconien et sa signification au sein des faciès moustériens. Thèse de doctorat. Université de Toulouse 2, p. 582.

Deschamps, M., Claud, E., Colonge, D., Mourre, V., Servelle, C., Thiébaut, C., 2013. Approche fonctionnelle des hachereaux du Paléolithique moyen récent de la région vasco-cantabrique. In: Palomo, A., Piqué, R., Terradas, X. (Eds.), Experimentación en arqueología. Estudio y difusión del pasado, 3er Congreso Internacional de arqueologia experimental, Banyoles, Girona, 17, 18 et 19 octobre 2011, Sèrie Monogràfica del MAC, pp. 199-208.

Deschamps, M., Servelle, C., Colonge, D., Mourre, V., 2011. Étude des ressources minérales dans l'environnement de la grotte du Noisetier. In: Mourre, V. (Ed.) Le site moustérien de la grotte du Noisetier à Fréchet-Aure (Hautes-Pyrénées), Fouille programmée annuelle 2011, SRA Midi-Pyrénées, pp. 68-77.

Djema, H., 2008. le Paléolithique moyen ancien de la corniche cantabrique et du bassin Aquitain ou le phénomène culturel des premiers néandertaliens. Thèse de doctorat. Université Panthéon-Sorbonne, Paris, p. 424.

Eixea, A., Roldán, C., Villaverde, V., Zilhão, J., 2014. Middle Palaeolithic flint procurement in central mediterranean Iberia: Implications for human mobility. Journal of Lithic Studies 1, 13.

Fabre, V., Condemi, S., Degioanni, A., 2009. Genetic evidence of geographical groups among neanderthals. Plos One 4 (4), 8

Féblot-Augustins, J., 1993. Mobility strategies in the late Middle Palaeolithic of central Europe and Western Europe: elements of stability and variability. Journal of Anthropological Archaeology 12, 211-265.

Fernandes, P., 2012. Itinéraires et transformations du silex: une pétroarchéologie refondée, application au Paléolithique moyen. Thèse dedoctorat. Université de Bordeaux1, p. 623.

Finlayson, J.-C., Barton, R., Stringer, C., 1998. The Gibraltar Neanderthals and their extinction, Les premiers hommes modernes de la péninsule ibérique. In: Actes du colloque de la commission VIII de l'UISPP, pp. 117-122.

Fortea, J., 1998. Abrigo de la Viña. Informe y primera valoración de las campañas de 1995 a 1998. Excavaciones Arqueologicas en Asturias 4, 31-41.

Fortea, J., 2001. El Paleolítico superior en Galicia y Asturias (1996-2000). In: Noiret, P. (Ed.), Le Paléolithique Supérieur Européen. Bilan Quinquennal 19962001. ERAUL, Liège, pp. 149-160.

Freeman, L.-G., González Echegaray, J., 1967. La industria musteriense de la cueva de la Flecha (Puente Viesgo-Santander). Zephyrus XVIII, 43-59.

Freeman, L.G., 1966. The nature of Mousterian facies in Cantabrian Spain. American Anthropologist 68 (2), 230-237.

Freeman, L.G., 1969-1970. El musteriense cantàbrico: Nuevas perspectivas. Ampurias 31-32, 55-69.

Freeman, L.G., 1994. Kaleidoscope or Tarnished Mirror? Thirty Years of Mousterian Investigations in Cantabria, Homenaje al Dr. Joaquin González Echegaray. Ministerio de cultura, Madrid, pp. 37-54.

Gamble, C.S., 1993. Exchange, foraging and local hominid networks. In: Scarre, C., Healy, F. (Eds.), Trade and Exchange in Prehistoric Europe: Proceedings of a
Conference Held at the University of Birmingham, April 1992. Oxbow Books in association with the Prehistoric Society and the Société préhistorique française, Oxford, pp. 35-44.

Geneste, J.-M., 1985. Analyse lithique d'industries moustériennes du Périgord: une approche technologique du comportement des groupes humains au Paléolithique moyen. Université de Bordeaux I, p. 567.

Gifford-Gonzalez, D., Damrosch, D.-B., Damrosch, D.-R., Pryor, J., Thunen, R.-L., 1985 The third dimension in site structure: an experiment in trampling and vertical dispersal. American Antiquity 50, 803-818.

González Echegaray, J., Freeman, L.G., 1971. Cueva Morin, excavaciones 1966-1968. Publicaciones del Patronato de las cuevas prehistoricas de la provincia de Santander VI, 452.

Gravina, B., Discamps, E., 2015. MTA-B or not to be? Recycled bifaces and shifting hunting strategies at Le Moustier and their implication for the late Middle Palaeolithic in southwestern France. Journal of Human Evolution 84, 83-98.

Guadelli, J.-L., 1987. Contribution à l'étude des zoocénoses préhistoriques en Aquitaine (würm ancien et interstade würmien). Thèse de l'Université de Bordeaux I, 3 t., p. 568

Guadelli, J.-L., 1996. Les Cerfs du Würm ancien en Aquitaine. Paléo 8, 99-108.

Guibert, P., Bechtel, F., Bourguignon, L., Brenet, M., Couchoud, I., Delagnes, A Delpech, F., Detrain, L., Duttine, M., Folgado, M., Jaubert, J., Lahaye, C., Lenoir, M. Maureille, B., Texier, J.-P., Turq, A., Vieillevigne, E., Villeneuve, G., 2008. Une base de données pour la chronologie du Paléolithique moyen dans le Sud-Ouest de la France. In: Jaubert, J., Bordes, J.-G., Ortega, I. (Eds.), Les socie_te_s du Pale_olithique du grand Sud-Ouest de la France: nouveaux gisements, nouveaux résultats, nouvelles méthodes, Mémoires de la Société Préhistorique Française, vol. 47, pp. 19-40.

Inizan, L.,M., Tixier, J., 1978. Outrepassage intentionnel sur pièces bifaciales néolithiques du Qatar (Golfe arabo-persique). Quaternaria 20, 29-40.

Iovita, R., McPherron, S., 2011. The handaxe reloaded: a morphometric reassessment of Acheulian and Middle Paleolithic handaxes,. Journal of Human Evolution 61, 61-74.

Iriarte, M.J., Gómez-Orellana, L., Muñoz-Sobrino, C., Ramil-Rego, P. Arrizabalaga, A. 2005. La dinámica de la vegetación en el NW peninsular durante la transición del Paleolítico Medio al Paleolítico superior. In: Montes Barquín, R., Lasheras Corruchaga, A. (Eds.), Neandertales Cantábricos, estado de la cuestión, vol. 20. Museo nacional y centro de Investigación de Altamira, Altamira, pp. 231-253.

Jaubert, J., 2013. Les archéo-séquences du Paléolithique moyen du Sud-Ouest de la France: Quel bilan un quart de siècle après François Bordes? 134ème Congrès national des sociétés historiques et scientifiques, colloque international François Bordes. CTHS 29, 235-253.

Jordá Cerdá, F., 1977. Historia de Asturias, Vitoria, Oviedo, 1. Prehistoria, p. 271.

Jöris, O., 2006. Bifacially backed knives (Keilmesser) in the central European middle palaeolithic. In: Goren-Inbar, N., Sharon, G. (Eds.), Axe Age: Acheulean Toolmaking from Quarry to Discard. Equinox, London, pp. 287-310.

Jöris, O., 2004. Zur chronostratigraphischen Stellung der spätmittelpaläolithischen Keilmessergruppen, Der Versuch einer kulturgeographischen Abgrenzung eine mittelpaläolithischen Formengruppe in ihrem europäischer Kontext. Bericht der Römisch-Germanischen Kommission 84, 49-153.

Laplace, G., Saenz de Buruaga, A., 2002. Typologie analytique et structurale des complexes du Moustérien de la grotte de Gatzarria(Ossas-Suhare, Pays Basque) et de leurs relations avec ceux de l'abri Olha 2 (Cambo, Pays Basque). Pyrenae 33-34, 81-163.

Laplace, G., Saenz de Buruaga, A., 2000. Application de la typologie analytique et structurale à l'étude de l'outillage moustéroïde de l'abri Olha 2 à Cambo (Kanbo) en Pays Basque. Paléo 12, 261-324.

Lazuén, T., 2012. Las primeras sociedades neandertales de la Región Cantábrica. In: BAR International Series, 2452, p. 261.

Lebègue, F., 2012. Le Paléolithique moyen récent entre Rhone et Pyrénées: approche de l'organisation techno-économique des productions lithiques, schémas de mobilité et organisation du territoire (Les Canalettes, l'Hortus, Bize-Tournal, la Crouzade et la Roquette II). Thèse de doctorat. Université de Perpignan Via Domitia, p. 797.

Lebègue, F. Wengler, L., 2014. Réflexions sur les modalités de circulation à distance des silex et la gestion du territoire à la fin du Paléolithique moyen dans l'angle nord-ouest de la Méditérranée. In: Otte, M., Le Brun-Ricalens, F. (Eds.), Modes de contacts et de déplacements au Paléolithique eurasiatique, Liège, 2012, vol. 140. ERAUL, pp. 437-472.

Lenoble, A., 2003. Le rôle du ruissellement dans la dormation des sites préhistoriques: approche expérimentale. Thèse de doctorat. Université de Bordeaux1, p. 306.

Lenoble, A., Bordes, J.-G., 2001. Une expérience de piétinement et de résidualisation par ruissellement. In: Bourguignon, L., Ortega, I., Frère-Sautot, M.-C. (Eds.) Préhistoire et approche expérimentale, pp. 295-311. Éd. M. Mergoil Montagnac.

Locht, J.-L., Depaepe, P., 2015. Le Paléolithique moyen récent en France septentrionale. In: Depaepe, P., Goval, E., Koehler, H., Locht, J.-L. (Eds.), Les plaines du Nord-Ouest. Carrefour de l'Europe au Paléolithique moyen?, Mémoire de la Société Préhistorique Française, vol. 59, pp. 61-73.

Mazo, C., Utrilla, P., Blasco, R., Mandado, J., Torres, T., Ortiz, E., Rink, J., 2011-2012. E nivel Musteriense de la cueva de Abauntz (Arraitz, Navarra) y su apportación al debate "vasconiense". Mainaké XXXIII, 187-214.

Minet, T., 2013. L'exploitation des silex au Paléolithique ancien et moyen dans l'avant-pays nord-Pyrénéen: approche gîtologique, pétroarchéologique et 
techno-économique, Université Toulouse - le Mirail. Mémoire de Master 2, 80.

Molines, N., Hinguant, S., Monnier, J.-L., 2001. Le Paléolithique moyen à outils bifaciaux dans l'ouest de la France: Synthèse des données anciennes et récentes. In: Cliquet, D. (Ed.), Les Industries à outils bifaciaux du Paléolithique moyen d'Europe occidentale, vol. 98. ERAUL, pp. 109-115.

Montes Barquín, R., 2003. El primer poblamiento de la region cantábrica, Monografías 18. Museo nacional y centro de investigación de Altamira, Madrid p. 260.

Mourre, V., 2003a. Discoïde ou pas Discoïde ? Réflexions sur la pertinence des critères techniques définissant le débitage Discoïde. In: Peresani, M. (Ed.), Discoid Lithic Technology - Advances and Implications. BAR International Series 1120 , Oxford, pp. $1-18$

Mourre, V., 2003b. Implications culturelles de la technologie des hachereaux. Thèse de doctorat. Université de Paris X - Nanterre, p. 880.

Mourre, V., Colonge, D., 2007. Et si l'Acheuléen méridional n'était pas là où on l'attendait? In: Évin, J. (Ed.), Congrès du centenaire: Un siècle de construction du discours scientifique en Préhistoire, Avignon, 21-25 septembre 2004, Bulletin de la Société Préhistorique Française, XXVIe congrès préhistorique de France, pp. 63-78.

Mourre, V., Colonge, D., Costamagno, S., Cravinho, S., Maureille, B., Niclot, M., Thiébaut, C., Viguier, J., 2005. Le site moustérien de la Grotte du Noisetier à Fréchet-Aure (Hautes-Pyrénées). In: Premier Rapport Intermédiaire, Fouille Programmée Pluriannuelle 2005-2007, p. 57.

Mourre, V., Bruxelles, L., Costamagno, S., Cravinho, S., Renvoisé, É., Thiébaut, C., Viguier, J., 2006. Le site moustérien de la Grotte du Noisetier à Fréchet-Aure (Hautes-Pyrénées). In: Deuxième rapport intermédiaire, Fouille Programmée Pluriannuelle 2005-2007, p. 58.

Normand, C., 1986. Inventaire des gîtes à silex de la Chalosse. Bulletin de la Société de Borda 402, 121-140.

Normand, C., 2002. Les ressources en matière première siliceuses dans la basse vallée de l'Adour et de ses affluents. In: Cazals, N. (Ed.), Comportements techniques et économiques des sociétés du Paléolithique supérieur dans le contexte pyrénéen, projet collectif de recherche service régional de l'archéologie de Midi-pyrénées, pp. 26-46.

Obermaier, H., 1924. Las diferentes facies del Musteriense espanol y especialmente de los yacimientos madrilenos. Revista de la Biblioteca archivo y museo 1 (2), 143-177.

Obermaier, H., 1925. El hombre fósil, Comision de Investigaciones Prehistoricas y Paleontologicas, vol. 9.

Palma di Cesnola, A., 1996. Le Paléolithique inférieur et moyen en Italie, L'Homme des origines. Jérôme Millon 1, 128.

Passemard, E., 1924. Les stations paléolithiques du Pays Basque et leurs relations avec les terrasses d'alluvions. Thèse de 3e cycle. Université de Strasbourg, p. 211

Pasty, J.-F., 2003. Le débitage Discoïde au Paléolithique moyen en Auvergne (France): une variabilité attendue. In: Peresani, M. (Ed.), Discoid Lithic Technology - Advances and Implications, BAR International Series 1120. Oxford, pp. 179-191.

Peresani, M., 2003. Discoid lithic technology - advances and implications. In: Peresani, M. (Ed.), BAR International Series 11200xford, p. 275.

Peyrony, D., 1920. Le Moustérien. Ses faciès. Association Française pour l'Avancement des Sciences 44, 496-497.

Pike-Tay, A., Cabrera Valdes, V., Bernaldo de Quirós, F., 1999. Seasonal variations of the Middle-Upper Paleolithic transition at El Castillo, Cueva Morín and El Pendo (Cantabria, Spain). Journal of Human Evolution 36, 283-317.

Porraz, G., 2005. En marge du milieu alpin - Dynamiques de formation des ensembles lithiques et modes d'occupation des territoires au Paléolithique moyen. Thèse de 3e cycle. Université de Provence, p. 386.

Richter, D., Dibble, H., Goldberg, P., McPherron, S., Niven, L., Sandgathe, D. Talamo, S., Turq, A., 2013. The late Middle Palaeolithic in Southwest France: new TL dates for the sequence of Pech de l'Azé IV. Quaternary International 294, 160-167.

Richter, D., Mauz, B., Böhner, U., Weißmüller, W., Wagner, G.A., Freund, G., Rink, W.J., Richter, J., 2000. Luminescence dating of the Middle/Upper palaeolithic sites "Sesselfelsgrotte" and "Abri I am Schulerloch", Altmühltal, Bavaria. In: Orschiedt, J., Weniger, G. Chr (Eds.), Neandertals and Modern Humans - Discussing the Transition. Central and Eastern Europe from 50.000-30.000 B. P., Mettmann, pp. 30-41.

Richter, J., 2006. Neanderthals in their landscape. In: Demarsin, B., Otte, M. (Eds.), Neanderthals in Europe. Université de Liège (ERAUL 117), Liège, pp. 51-66.

Ríos-Garaizar, J., 2012. Industria lítica y sociedad en la Transicion del Paleolítico Medio al Superior en torno al Golfo de Bizkaia. PUbliCan - Ediciones de la Universidad de Cantabria, Santander.

Rodríguez Asensio, J.A., 1983. La presencia humana más antigua en Asturias. In: Estudios de Arqueología Asturiana, 2. Oviedo.

Rodríguez Asensio, J.A., Arrizabalaga, A., 2004. El poblamiento más antiguo de la región: las ocupaciones previas al IS4. Desde el inicio del poblamiento a circa 80.000 BP. In: Fano, M. (Ed.), Las sociedades del Paleolítico en la región cantábrica, vol. 8. KOBIE (Serie Anejos), pp. 51-90.

Roebroeks, W., 1988. From Find Scatters to Early Hominid Behaviour. A Study of Middle Palaeolithic Riverside Settlements at Maastricht-belvédère (The Netherlands). Leiden University Press, Leiden.

Rots, V., 2009. The functional analysis of the Mousterian and the Macoquian assemblages os Sesselfelsgrotte, Germany: aspect of tool use and hafting in the European Late Middle Palaeolithic. Quartär 56, 37-66.
Ruebens, K., 2012. From Keilmesser to Bout-coupé Handaxes: Macro-regional Variability Among Western European Late Middle Palaeolithic Bifacial Tools (PhD thsesis). University of Southampton, p. 381.

Ruebens, K., 2013. Regional behaviour among late Neanderthal groups in Western Europe: a comparative assessment of late Middle Palaeolithic bifacial tool variability. Journal of Human Evolution 1-22.

Ruebens, K., 2014. Late middle Palaeolithic bifacial technologies across northwest Europe: typo-technological variability and trends. Quaternary International 350, 130-146.

Ruebens, K., McPherron, S., Hublin, J.-J., 2015. On the local Mousterian origin of the Châtelperronian: integrating typo-technological, chronostratigraphic and contextual data. Journal of Human Evolution 86, 55-91.

Ruebens, K., Wragg Sykes, R., 2016. Spatio-temporal variation in late Middle Palaeolithic Neanderthal behaviour: British bout coupé handaxes as a case study. Quaternary International 1-22 (in press).

Saenz de Buruaga, A., Ebrard, D., 2004. El Musteriense de la cueva de Harregi en Aussurucq, Soule (Excavationes: Pierre Boucher, 1954-1960). Veleia 21, 9-39.

Sanchez Fernández, G., Bernaldo de Quiros, F., 2008. El final del Musteriense cantabrico: el nivel 20e de la cueva de el Castillo (Cantabria). In: Ramil Rego, E. (Ed.), Congreso Internacional de Arqueoloxía de Vilalba, Fervedes, 5, pp. 11-14 junio 2008.

Sanchez-Goñi, M., D'Errico, F., 2005. La historia de la vegetacion y el clima del ultimo ciclo climatico (OIS5-OIS1, 140000-10000 anos BP) en la Peninsula Iberica y su posible impacto sobre los grupos paleoliticos. In: Montes, R., Lasheras Corruchaga, A. (Eds.), Neandertales cantabricos: Estado de la question, Monografías 20. Museo nacional y centro de Investigación de Altamira, pp. $115-129$.

Sanchez-Goñi, M., Landais, A., Fletcher, W., Naughton, F., Desprar, S., Duprat, J., 2008. Contrasting impacts of Dansgaard-Oeschger events over a western European latitudinal transect modulated by orbital parameters. Quaternary Science Reviews 27, 1136-1151.

Sanguino González, J., Montes Barquin, R., 2001. Un yacimiento con mucha historia, La cueva de El Pendo. In: Actuaciones Arqueologicas 1994-2000, Ayuntamiento de Camargo, Consejeria de Cultura, Turismo y Deporte. Santander, pp. 17-23.

Sanguino González, J., Montes Barquín, R., 2005. Nuevos datos para el conocmiento des Paleolítico Medio en el centro de la Región Cantábrica: La Cueva de Covalejos. In: Montes Barquín, R., Lasheras Corruchaga, A. (Eds.), Neandertales cantábricos, estado de la cuestión, Monografias 20. Museo nacional y centro de Investigación de Altamira, pp. 505-526.

Santamaria, D., 2012. La transicion del Paleolítico medio al superior en asturias. El abrigo de la Viña (La manzaneda, Oviedo) y la cueva de el Sidrón (Borines, Piloña). Tesis doctoral. Universidad de Oviedo, p. 1518.

Santamaria, D., Rasilla (de la), M., 2013. Datando el final del Paleolítico medio en la Península Ibérica. Problemas metodologicos y límites de la interpretación, trabajos de Prehistoria 70 (2), 241-263.

Santonja, M., Pérez-González, A., Panera, J., Rubio-Jara, S., Méndez-Quintas, E., 2016. The coexistence of acheulean and Ancient middle palaeolithic techno- complexes in the middle pleistocene of the Iberian Peninsula. Quaternary International 1-11 (in press).

Santonja, M., Villa, P., 2006. The acheulean of Western Europe. In: Goren-Inbar, N., Sharon, G. (Eds.), Axe Age, Acheulian Tool-making from Quarry to Discard. Equinox Publishing, pp. 429-478.

Séronie-Vivien, M.-R., 2006. L'économie du silex au Paléolithique suprieur dans le bassin d'Aquitaine. Paleo 18, 193-216.

Séronie-Vivien, M.-R., Séronie-Vivien, M., Foucher, P., Millet, D., Millet, F., 2012. Entre l'Adour et la Baïse (partie occidentale du Gers, France): une importante source de matières premières siliceuses du Sénonien. Paleo 23, 357-366.

Slimak, L., 2001. Moustériens Quina rhodaniens et Quina classiques dans le SudOuest de la France, Territoires, déplacements, mobilité échanges durant la Préhistoire. In: Actes du 126 ème congrès du CTHS, Toulouse, pp. 95-113.

Soressi, M., 1997. Analyse technologique d'un assemblage Moustérien de tradition acheuléenne du sud- ouest de la France: la couche G du Moustier, 2 vol. Université Bordeaux I, Mémoire de D.E.A., p. 119 et 143 pp.

Soressi, M., 2002. Le Moustérien de tradition acheuléenne du sud-ouest de la France. In: Discussion sur la signification du faciès à partir de l'étude comparée de quatres sites: Pech-de-l'Azé I, Le Moustier, La Rochette et la grotte XVI. Université de Bordeaux I, p. 330.

Tarriño Vinagre, A., 2006. El sílex en la cuenca vasco-cantábrica y pirineo navarro, caracterización y su aprovechamiento en la prehistoria. Museo nacional y centro de Investigación de Altamira Monografías 21, 263.

Tarriño Vinagre, A., Elorrieta, I., Garcia-Rojas, M., 2014. Flint as raw material in prehistoric times: Cantabrian Mountain and Western Pyrenees data. Quaternary International 364, 94-108.

Thibault, C., 1970. Recherches sur les terrains quaternaires du bassin de l'Adour, Bordeaux, p. 814.

Thiébaut, C., 2005. Thèse de doctorat. Le Moustérien à denticulés: variabilité ou diversité techno-économique ?, 2 vol. Université de Provence, p. 870

Thiébaut, C., Claud, E., Costamagno, S., Coudenneau, A., Coumont, M.-P., Deschamps, M., Gerbe, M., Mallye, J.-B., Mourre, V., Asselin, G., Beauval, C. Brenet, M., Chacón, M.G., Maury, S., Paravel, B., Provenzano, N., Soulier, M.-C., 2009. Des traces et des hommes Projet interdisciplinaire pour interpréter les comportements techno-économiques des Néandertaliens. Les nouvelles de l'archéologie 118, 49-55.

Thiébaut, C., Claud, E., Deschamps, M., Discamps, E., Soulier, M.-C., Mussini, C., Costamagno, S., Rendu, W., Brenet, M., Colonge, D., Coudenneau, A., Gerbe, M., 
Guibert, P., Jaubert, J., Laroulandie, V., Maureille, B., Mourre, V., Santos, F., 2014. Diversité des productions lithiques du Paléolithique moyen récent (OIS 4-OIS 3): enquête sur le rôle des facteurs environnementaux, fonctionnels et culturels. In: Thiébaut, C., Claud, E., Costamagno, S. (Eds.), XXVIIe congrès préhistorique de France, session E, Exploitation des ressources organiques à la fin du Paléolithique moyen et au début du Paléolithique supérieur: interactions entre environnement et comportements techniques, Bordeaux - Les Eyzies 31 mai-5 juin 2010, pp. 281-298.

Thiébaut, C., Costamagno, S., Coumont, M.-P., Mourre, V., Provenzano, N., ThéryParisot, I., 2010. Approche expérimentale des conséquences du piétinement des grands herbivores sur les vestiges lithiques et osseux. In: Thiébaut, C., Coumont, M.-P., Averbouh, A. (Eds.), Mise en commun des approches en taphonomie, actes du workshop $\mathrm{n}^{\circ} 16-\mathrm{XVe}$ congrès international de l'UISPP, Lisbonne, Paléo - supplément, 3, pp. 109-130.

Thiébaut, C., Mourre, V., Chalard, P., Colonge, D., Coudenneau, A., Deschamps, M., Sacco-Sonador, A., 2012. Lithic technology of the final Mousterian on both sides of Pyrenees. Quaternary International 247, 182-198.

Tixier, J., 1956. Le hachereau dans l'Acheuléen nord-africain - Notes typologiques. In: Congrès préhistorique de France - Compte-rendu de la XVème session Poitiers-Angoulême - 15-22 juillet 1956, pp. 914-923.

Tixier, J., 1978. réed. 2012. Méthode pour l'étude des outillages lithiques. Centre National de Recherche Archéologique du Luxembourg.

Torre (de la), I., Martinez-Moreno, J., Mora, R., 2014. Change and stasis in the iberian middle Palaeolithic. Current Anthropology 54 (8), 320-336.

Turq, A., 2000. Le Paléolithique inférieur et moyen entre les vallées de la Dordogne et du Lot. Paléo, Hors série 2, 456.

Turq, A., Geneste, J.-M., Jaubert, J., Lenoir, M., Meignen, L., 1990. Les moustériens charentiens du Sud-ouest et du Languedoc-oriental: approche technologique et variabilité géographique. In: Les Moustériens Charentiens, Colloque International, Brive, La Chapelle-aux-saints, pp. 53-64.

Turq, A., Roebroeks, W., Bourguignon, L., Faivre, J.-P., 2013. The fragmented character of Middle Palaeolithic stone tool technology. Journal of Human Evolution 65 (5), 641-655.
Utrilla, P., 2000. El Paleolitico en el valle Medio del Ebro: Una "revista de prensa" en el cambio de milenio. SPAL 9, 81-108.

Uzquiano Ollero, P., 2005. El registro antracologico durante la transicion Musteriense-Paleolitico superior inicial en la region cantabrica: vegetacion paleoambiente y modos de vida alrededor del fuego. In: Barquin, R., Lasheras Corruchaga, A. (Eds.), Neandertales cantabricos: estado de la cuestion, Museo nacional y centro de Investigación de Altamira, Altamira, Monografías 20, pp. 255-274.

Valladas, H., Geneste, J.M., Joron, J.L., Chadelle, J.P., 1986. Thermoluminescence dating of Le Moustier (Dordogne, France). Nature 322, 452-454.

Van Peer, P., 1992. The Levallois Reduction Strategy. Prehistory press, Madison.

Vega del Sella, c.d.l, 1921. El Paleolítico de Cueva Morín (Santander) y notas para la climatologia cuaternaria, Comisíon de Investigaciones Paleontológicas y Prehistóricas, Memoria $n^{\circ} 29$, (Serie prehistórica, $n^{\circ} 25$ ). Museo Nacional de Ciencias Naturales, p. 167.

Vieillevigne, E., Bourguignon, L., Ortega, I. Guibert, P., 2008. Analyse croisée des données chronologiques et des industries lithiques dans le grand sud-ouest de la France (OIS 10 à 3). Paleo 20, 145-166.

White, M.J., Jacobi, R.M., 2002. Two sides to every story: bout coupé handaxes revisited. Oxford journal of Archaeology 21 (2), 109-133.

White, M.J., Pettitt, P.B., 2011. The British late middle palaeolithic: an interpretative synthesis of Neanderthal occupation at the northwestern edge of the pleistocene world. Journal of World Prehistory 24, 25-97.

Wragg Sykes, R., 2009. Neanderthals in Britain: Late Mousterian Archaeology in Landscape Context. Thèse de doctorat. University of Sheffield, p. 854.

Wragg Sykes, R., 2010. Beyond Bout coupés: the dynamic role of Bifaces in the British Mousterian. The Lithics Studies Society 31, 20-32.

Yravedra, J., 2007. Nuevas contribuciones en el comportamiento cinegético de la Cueva de Amalda. Munibe 58, 43-88.

Zilhão, J., 2006. Chronostratigraphy of the middle-to-upper Paleolithic transition in the Iberian Peninsula. Pyrenae 37 (1), 7-84

Zilhão, J., Villaverde, V., 2008. The middle paleolithic of Murcia. Treball's d'Arqueologia 14, 229-248. 